\title{
Anti-corruption revisited: the case of the Czech Republic and Slovakia
}

\author{
Nicole Gallina
}

\begin{abstract}
Corruption is an urgent problem in both the Czech Republic and Slovakia. Whereas the new Czech government has pushed anti-corruption plans, in Slovakia, a special court and prosecution office are in place facing constant challenges. In both countries, the issue has been highly politicised and the adaptation of anti-corruption institutions as well as the implementation of legislation have been poor. This paper examines whether those shortcomings can be explained by elite-based "politics of corruption". Basically, on a general scale, the paper shows the relation between politics and corruption and identifies a gap between anti-corruption efforts and results. The conclusion finds that anti-corruption in both states has no serious political base while, depending on single personalities, there have been some achievements in this respect in both the Czech Republic and Slovakia.
\end{abstract}

Keywords: Anti-corruption $\cdot$ Political elites $\cdot$ Czech Republic $\cdot$ Slovakia

\section{Anti-Korruptions-Strategien in der Kritik: Tschechien und Slowakei als Analysefälle}

Zusammenfassung: Korruption stellt sich als dringendes Problem sowohl in der tschechischen Republik als auch in der Slowakei dar. Zwar wurden in beiden Staaten verschiedene Anti-Korruptions-Gesetze oder -Institutionen etabliert, dennoch bleibt Korruption eine konstante Herausforderung. In beiden Staaten bleiben Anti-Korruptions-Maßnahmen erheblich politisiert und die Umsetzung der installierten Anti-Korruptionsmaßahmen verbleibt auf niedrigem Niveau. Der Beitrag erarbeitet den Nexus zwischen der politischen Sphäre und der verbreiteten Korruption und erklärt die geringen Implementationserfolge in der Anti-Korruptionspolitik beider Staaten.

Schlüsselwörter: Anti-Korruption · Politische Eliten · Tschechische Republik · Slowakei

Published online: 17.09 .2013

(C) Springer Fachmedien Wiesbaden 2013

Dr. N. Gallina $(\bowtie)$

Interfaculty Institute for Central and Eastern Europe, University of Fribourg,

Bd. de Pérolles 90, 1700 Fribourg, Switzerland

e-mail: nicole.gallina@unifr.ch 


\section{Introduction}

"It was our feeling that he (=the former Czech Interior Minister Radek John) abused the name of Transparency International (...), and we needed to stress somehow that not all of his opinions are based on our advice (...). What John presented was, from our point of view, partly pre-election campaigning for the municipal elections." According to TI Czech Republic the anti-corruption plan "contained too many repressive measures and too few preventive ones" (The Prague Post 2010). This was the first setback to the new Czech government installed in 2010 explicitly on the anti-corruption ticket.

The statement of TI Czech Republic points to an overall and urgent problem of anticorruption politics. The issue on corruption has been misused to generate political support, in particular during election times. The VV (Věci veřejné) party was elected on this ticket, and formed a government with the conservative parties ODS (the Civic Democratic Party) and TOP09 in 2010. But the Nečas government's promises have not fully matched with actual anti-corruption measures, the VV party disintegrated and the prime minister had to resign in July 2013 in the context of various corruption scandals and corruption remains an urgent problem in the country. ${ }^{1}$ In fact, the above TI statement underlines the gap between anti-corruption rhetoric and actual anti-corruption deeds, as seen in the Czech case.

A striking fact is that most oppositional political parties in East Central Europe have a strong focus on anti-corruption. This has been especially valid for the Czech Republic as oppositional parties have run on an anti-corruption ticket in election campaigns. Assuming government responsibility, the former oppositional and later governing parties abandoned or delayed law projects as a rule, and the former governing and later oppositional parties accused the new rulers of corruption. In Slovakia this occurred as well, but the anti-corruption efforts account has been more favourable (on the first sight), even if the authoritarian government of Vladimir Mečiar first pointed in another direction. The Mečiar government experience, paved the way for a policy change. In the course of time, independent institutions were established, such as a separate court and prosecution office. Here, anti-corruption rhetoric was accompanied by the will to combat corruption, especially right after the fall of the Mečiar regime.

On a general scale, this paper examines the relationship between politics and corruption focussing on the Czech Republic and Slovakia in the first two decades of independence. It first outlines theoretical and methodological aspects. The paper then presents the politics of anti-corruption in both countries. The underlying research questions can be posed as follows: How have political elites incorporated (anti-)corruption politics and what instruments do they use? Therefore the attempt is made to disaggregate multiple factors of corruption and to identify forms of corruption and the nature of anti-corruption efforts as well as their effectiveness for each government period.

1 In the end, almost half of the citizens equated the VV party with corruption ( $44 \%$ of the polled), http://www.ceskatelevize.cz/ct24/domaci/172796-kdyz-se-rekne-korupce-lide-si-vybavi-vva-bartu/. On anti-corruption politics for example or http://www.respektinstitut.cz/wp-content/ uploads/2012/07/Metodika-o-korupci-Respekt-institut.pdf or http://www.dbm.cz/pruzkumy/ english/?id=98 (Accessed 20 Oct 2012). 


\section{Corruption in the Czech Republic and Slovakia: some theoretical insights}

The points of departure are similar for both countries. After their separation, the Czech Republic and Slovakia have been two independent states and parliamentary democracies since 1993. ${ }^{2}$ This had several implications: Young democracies are not as institutionalized as established Western European democracies, as is for instance visible in the volatility of their political party systems (e.g. Henderson 2002). The weak institutionalization could foster corruption - if parties cannot be sure about long-term electoral support, their members could try to get "the best out of it". A recent example might be the government of Robert Fico's governing periods (2006-2010), or various no-confidence votes, placing narrow political party interests above the nation's well-being (Freedom House 2010). An example of this would be the opposition-initiated no-confidence vote in 2010 during the Czech EU presidency which proved the political elite's incapability to reach a consensus across party lines and re-opened political options.

According to the neo-classical approach, corruption is a problem that resides in the broader processes through which consent is won and authority is used. Typical examples are abuses of office positions or resources for private benefit. In certain states the principals (=the political decision-makers) and their agents are affected: the agent's decision is influenced by remuneration, which is not passed on to the principal (Rose-Ackerman 1978, p. 6). In Central Eastern European countries principals and agents affect politics in a rather undemocratic way through corruption and place themselves above the democratic structures they operate in. Actors do not behave according to their democratic mandate, and do little to advance the common good; instead, they almost exclusively consider their personal well-being, for example in corrupting public procurements or privatizations (Gallina 2008, p. 47, compare with Pehe 2009).

\subsection{The role of corruption in democracies}

Nowadays, there is a rather common understanding that political corruption can pose a serious threat to democracy, as Larry Diamond underlined as early as 1992. Rose-Ackerman (2001, p. 35 f.) examined some features of democratic systems that determine the "extent to which the design of the political system affects the development of corruption" in the society. The difference between the election of political leaders and the role which political parties play leads to various forms of interest being incorporated in various sectors. The level of corruption in a society depends upon the extent to which a political system's design is congruent to public expectations.

In this paper, I will offer a different view: the nature of corruption is also reliant on the extent to which a political system's design conforms to the needs of its elites. The young democratic history of both countries and the weak institutionalization of certain democratic pillars, such as political parties that compete for power within a democratic framework, might require a shift in perspective from institutions (i.e. government or political

2 Until then, the two countries were united as Czechoslovakia. Czechoslovakia had been a democracy in the inter-War period from 1918 to 1938. In 1993 the two parts split peacefully into two sovereign states. 
parties) to actors. Actors - political, economic and judicial decision-makers - might not fully consent to certain requirements of the democratic system. This paper therefore suggests that the dynamics of the political elite have a strong impact on the degree and types of corruption.

Such a view does not exclude the important role of "intermediaries". Intermediary groups seek contacts with powerful people, and aim at a personal share of power (Johnston 2001, p. 14). Dennis Thompson has introduced the notion of "mediated corruption" in case when corrupt acts are mediated (=filtered) by the political process (Thompson 1993, p. 369). Rose-Ackerman (1978, p. 6) underlines the agency relationship between the authority and the inspector. Corruption arises when a third person seeks to influence the agent's decision by offering remuneration which is not passed on to the principal. An environment enabling a strong position of the agent fosters corruption. Regarding Slovakia and the Czech Republic, unstable governments and the understanding of political parties as instruments to maximize personal interests strengthen an agent's position. Both factors also widen the opportunities for corruption for the principal, especially with regard to a politically dependent judiciary.

\subsection{Why political elites, why corruption?}

Political elites are "persons who are able, by virtue of their strategic positions in powerful organizations and movements, to affect political outcomes regularly and substantially" (Higley and Burton 2006, p. 7). An actor-centred institutionalism emphasises the role of political elites and their political instruments.

The Central European research perspective has to bear in mind that it is still the case that most political elites were socialized in a socialist environment with predominantly informal governing instruments. This can partly be explained through centralized command economies, which implied for example façade policy through five-year plans. Lack of technical facilities and sectoral requirements fostered corruption in various ways. In this regard, Tanzi (1998) underlines the importance of corruption in the communist space.

Informal instruments have continued to be very important after 1989, as for instance Lauth (2000), Haughton (2005) or Hayoz and Gallina (2011) have shown. In 1999, the EBRD argued that the quality of the institutional environment and governance structures in the Czech Republic is one of the lowest in the region. The reason why elites in Eastern Europe might opt for informal practices is connected with reluctance towards formal structures and rule of law (Lauth 2004). Meyer et al. (2008) have considered how informal practices of political elites influence political power, and hinted at forms of corruption. In this regard, I undertake an attempt to identify the nature of (anti-)corruption politics and anti-corruption efforts.

\subsection{On the degree of corruption}

How can we link political elites to the degree of corruption? The common view that corruption might be a legacy of a socialist past does not help analyse the degree of corruption. Also, the insights of Miller et al. (2000, p. 141) offer little insight: they point out that corruption might be far more institutionalized than commonly assumed. This points to a 
connection between political elites - through the formal democratic institution of political parties - and corruption. Political elites avoid being directly involved in this business, but with the help of agents, it is possible to establish the necessary networks (see some examples in the case studies below).

Della Porta et al. (1999) propose an impressive analysis of the Italian corruption example where various actors were connected, often across party lines, in an invisible organizational structure. Corruption was (or is) a multi-headed collection of networks gathered around individuals, with little coordination from above.

On a general scale, Eastern European countries achieve more problematic results on corruption ratings than Western European countries - only Italy (72) and Greece (94) rate worse than almost all Eastern European countries on the 2012 Transparency International Corruption Perceptions Index. The Czech Republic and Slovakia rank 54 and 62 respectively. ${ }^{3}$

Even if Kotkin and Sajó (2002, p. 1) argue that the problem of corruption in Eastern Europe has been overstated. However, "Nations in Transit 2006 warned of the enduring problem of corruption, yet three years later, corruption continued to pose a major obstacle," in spite of less petty corruption which resulted in declining corruption rates (Freedom House 2009). Data from Transparency International, Freedom House and domestic organizations are in line with regional findings of a high salience of corruption in the region. ${ }^{4}$

The importance of corruption among political elites is underlined by the fact that in all major cases shown here, high political representatives and also prime ministers have been highly suspected to be involved. The current degree of political corruption also could be linked to the fragmentation of the political party system, which is split into different political elite groups or single persons who "work" on their own. As political party members are at odds with each other, there is little party cohesion (Gallina 2008). ${ }^{5}$ Researchers such as Ágh (1998), Bielasiak (2005) and Lewis (1996) have described the fragmentation of the political space; Henderson (2002) has especially considered the problem of political party fragmentation in Slovakia and the Czech Republic. The fragmented political party system could be a reason for the persistence and strength of old (power) structures and behaviour patterns.

Tim Haughton (2005) argues in the case of Slovakia that the role of leadership in the region might not match Western European understandings of political elite rule. Kopecký (2006) emphasised rent-seeking methods to enhance influence, and the reliance on politi-

3 On the 2011 CPI-Corruption Perceptions Index the Czech Republic and Slovakia rank 57 and 66, compared for example with 2010 when they ranked 53 and 59 respectively http://cpi.transparency.org/cpi2012/results/ (Accessed 10 Mar 2013).

4 See the tables in the annexe of this work on CPI and Freedom House assessments of corruption in the two countries. Local organizations underline that the perception of corruption remains high, see for example the CVVM report (2011) on corruption perception in the public service in the Czech Republic (Accessed 01 Oct 2011).

5 Recent examples are the Slovak vote on the EU bailout fund in October 2011 which led to the fall of the Radičová government; or disputes within the VV party and the Social-Democratic Party in the Czech Republic in autumn 2011. 
cized ties to interact with independent institutions and society. Corruption could be the underlying glue that pastes political elites together, more than the typical democratic government-opposition scheme. ${ }^{6}$

Methodological problems arise when trying to capture the degree of corruption. Corruption measures have succeeded in supporting empirical work, but they quantify only the activities that are easily identifiable as corruption (Arvind 2001, p.9). Undiscovered cases remain beyond corruption ratings such as Transparency International; moreover, government statistics additionally do not tell which corruption cases have been monitored or resolved (Sičáková-Beblavá and Nechala 2006, p. 7). "If corruption could be measured, it could probably be eliminated," and simply measuring bribes ignores many further forms of corruption (Tanzi 1998, p. 567). Often, ratings concentrate on narrow social groups, for example businessmen, who do not necessarily report real acts, and add their own perceptions, include exaggerations or false reports (compare with The World Bank 2000a).

\subsection{Types of corruption}

Most authors distinguish between low-level (petty corruption, bribing low-level bureaucrats and employees) and high-level corruption. Lízal and Kocenda (2001, p. 141) citing Czech GfK reports argue that private sectors show a decline in perceived corruption, and state administration in contrary has experienced an increase. But according to reports the situation changed in the 2000s. In the period between 2002 and 2005 administrative corruption in Slovakia decreased significantly. ${ }^{8}$

Here, the focus is on high-level corruption in the Czech Republic and in Slovakia. The core sectors are the police, state prosecution and the judicial system as well as tax and fiscal authorities. ${ }^{9}$ These types are predominantly connected to the inner realm of the state and bureaucratic apparatus where political elites abuse their power, and seek connections with private (but also state) businesses.

High-level corruption includes public tenders and monopolies, ${ }^{10}$ party financing and election campaigns. Most forms rely on the intermediary role of agents, meaning magnates or oligarchs, but also criminal groups. High-level corruption typically reaches in the

6 See the Economist (2011). The grim assessment is criticized by the then Interior Minister Kubice (Respekt 2011b). The following website lists the most important corruption cases in the Czech Republic and shows the varieties of corruption in the country that do not follow party lines, and supports the underneath argument that political elites cannot be differentiated in this respect. http://kmotrdrobek.jex.cz/menu/afery-a-korupce/afery-v-politice (Accessed 15 Oct 2011).

7 On detailed degrees and perceptions of corruption see the Transparency International Slovakia reports named "Protikorupčné Minimum", Sičáková-Beblavá (2011) and Lízal and Kocenda (2001) for the Czech Republic (until 2001).

8 A large survey of firms found that levels of administrative corruption came down, in particular in Slovakia (Rousso and Stevens 2006: 264).

9 Corruption in the education and the health sector has been important, but falls under sectoral corruption that most often does not has political connections. An interesting case were the false law degrees assigned by the Plzeň University until 2009 (Radio Prague 2009).

10 Lízal and Kocenda (2001, p. 146) argue that most cases of corruption are connected to public tenders. 
outer world, and corrupts the most influential branches of society. Critics could point to a rather artificial or blurred definition of high-level corruption, but what these types have in common is that they are managed by political elites (or at least political elites try to keep control over those corrupted connections and networks). ${ }^{11}$

Best and Becker (1997) as well as Higley and Lengyel (2000) emphasise that power elites adhere to a quasi-identical scheme of conduct even if they have different backgrounds, namely career politicians such as political party leaders, ministers, and prime ministers. This could strengthen the argument that political elite-connected types of corruption are similar or virtually identical.

Spinney (2011) builds on the insights of psychological analysis (e.g. Lammers and Galinsky) and argues that corruption is an outcome of power. The more power somebody feels that he has, the more he tends to be corrupted. Even within a democratic system, politicians, or the political elite, might feel so powerful in terms of perceived power that they tend to corrupt the system. As political elites exert significant political influence and maintain powerful personal networks they are prone to become drivers for corruption and might encourage others to corrupt them. The Czech political scientist Bohumil Doležál (Spurný 2007a, b) argued that a political elite culture of corruption runs across all political parties or high-level politicians. Tanzi (1998, p. 18) added that top political leaders do not provide the right example, either because they engage in acts of corruption or because they condone such acts on the part of relatives, friends, or political associates. Therefore, public administration employees, state prosecutors or judges do not behave differently. ${ }^{12}$ Based on these arguments, the focus of this case study is political elite-driven corruption in the Czech Republic and Slovakia. The case studies examine (anti-)corruption politics, focusing on the types of corruption, the instruments of preventing anti-corruption, and the nature of political elite anti-corruption efforts.

\subsection{How to combat corruption}

If political elites have incorporated corruptive behaviour and built corruptive circles within state structures and additionally included economic sectors, what kind of anticorruption measures would work? Ivan Krastev (2004) has drawn a rather grim conclusion of his respective research in underlining the ineffectiveness of anti-corruption campaigns in general. Spurný (2007a) argued that the politicization of the police and justice sphere has predominantly hindered anti-corruption efforts. One might also add the explanation of Mungiu-Pippidi (2006, p. 86) that anti-corruption efforts have been antipolitical in nature and have therefore failed.

The advocates of anti-corruption usually emphasize three aspects (e.g. The World Bank 2000a; Klitgaard 1988): to introduce new or amended legislation that reduces

11 See the case of ČEZ CEO Martin Roman, the biggest state-owned energy group in the country. He was suspected to have contacts to his former private employer Škoda Plzen - the case is allegedly linked to MUS (see footnote 20; ČTK 2011).

12 Rose-Ackerman (1999) shows the various possibilities of how to influence major government programs and policy areas. Lízal and Kocenda (2001) have discussed those problems in regard to the Czech Republic. 
opportunities for rent-seeking; to build alliances with other governments in the struggle against corruption (international anti-corruption treaties, organizations), and to implement an integrated anti-corruption program, for instance according laws plus anti-corruption agencies.

Thus, anti-corruption efforts should refer to individual reasons of corruption. De-politicization of the state administration that prevents high-level political corruption through independent judiciary agencies, public or independent control of intelligence on the one hand, and public internet biddings or the prevention of monopolies on the other hand. "Monopolies must be reduced or carefully regulated" (Klitgaard 1998, p. 2), and the politicization of anti-corruption efforts is necessary.

Examples were the anti-corruption measures in Slovakia (Sičáková-Beblavá and Beblavý 2008) which consider the inner political sphere and the interaction with the economic realm. They include the privatization of banks or the registering of real estate, as well as the free access to information such as public biddings. On the political side they focus on budget regulation of local administrations, supervision of political party financing, court management and the establishment of a special court and state prosecution. Interestingly, there are no instruments which are explicitly called political in the Slovak strategy. So-called administrative instruments would have the most serious political implications and, an efficient system of independent control of the supposedly corrupted political elite would tend to hinder corruption in general.

\subsection{Obstacles of anti-corruption politics}

To identify the sincerity of anti-corruption proposals has not been easy. Measures proposed have usually not been implemented or remained vague. Political elite-led anticorruption packages are rarely effective; just consider the instruments proposed in 2010 by the Nečas government in the Czech Republic.

One core obstacle is that political elites try to politicize independent or control institutions through, for example, tight relations between ministers and police presidents or state prosecutors. Further obstacles are formed by regulations that impede investigation in corruption cases whereby agencies are only allowed to examine economic corruption. Such regulations do not advance anti-corruption.

Anti-corruption efforts have to consider political realities. Does their effectiveness depend on party rule? Deegan-Krause (2006) pointed to changing rhetoric according to a government-opposition scheme in a post-socialist space related to a virtually identical conduct of ideologically different governing and oppositional parties. Incumbents do little to combat corruption, oppositional parties plead for strong anti-corruption instruments, but when in power they fall silent on the topic. For the case of Slovakia, DeeganKrause (2009, p. 839) states that the country has a "clean-corrupt" divide. This divide cuts across other political cleavages. In the end, the sides of "clean" and "corrupt" are not clear as "the roster" changes continually, clean parties and political leaders might quickly change to corrupt ones, and new clean parties come to be perceived as corrupt. In the Czech Republic and Slovakia we can consider the phenomenon of new anti-corruption protest parties. It is yet to be seen whether those parties can meet voters' high expectations and if they will be re-elected-recent experience did not give cause for much hope. 


\subsection{Variations of elite strategies}

Basically, political elites' behaviour can be analysed according to various strategies:

- Political power elites do not want and do not have to control corruption, for example during the Mečiar reign in Slovakia and the "opposition agreement" in the Czech Republic which meant a co-governing between the conservative Civic Democratic Party ODS and the Social-Democratic Party ČSSD in the late 1990s. Corruption could also not be an issue (Czech Republic pre-1997).

- Political power elites do not want to propose measure, but are forced to do so by public pressure, mostly connected to elections. Examples are the post-Mečiar period or the Topolánek government in the Czech Republic. These measures are designed in such a way that their implementation fails or is too weak to tackle the corruption problem.

- Oppositional elites propose measures which they abandon or largely ignore once they assume office, for instance certain parties in the Czech government after the 2010 elections. The Fico governments in Slovakia also largely fall in this category.

- Political power elites want, and do propose measures - often against the will of other power elites. These are implemented, but the implementation issue remains important as political opponents or strong networks, for example in the sphere of justice, might sabotage them directly. During the Dzurinda governments in Slovakia certain governing elites did want to act, especially during his second government. They indeed proposed and implemented measures.

Mainly, the last argument leads to important questions on accountability. I assume that electoral accountability has been of little importance to political elites in general as the government-opposition scheme does not work, and both sides try to get the best out of it. For instance, the institutional demands for corruption are more significant than the fear of accountability. In addition to this, public or media accountability plays a role as well. This could lead to institutional accountability in the form of an anti-corruption police and courts. The question is how effective institutional accountability is in the long term.

The challenge for research is to give a structured account of the factors of anti-corruption as identified above. This paper is based on research conducted in the Czech Republic and Slovakia in 2007 and 2008 (Gallina 2008). The goal was to map the elite's conduct and their willingness to apply informal rules and structures over formalized regulation and institutionalized agencies. Media analysis and interviews with outside experts were used to give a structured analysis of political elite behaviour. ${ }^{13}$ The starting point of this

13 Elite interviews would have provided a biased result. The qualitative research was based on expert interviews, international NGO insights (Transparency International and others), and well-respected newspapers, such as the Swiss daily Neue Zürcher Zeitung and The New York Times, and national coverage by the investigative Czech weekly Respekt and daily Mladá Front Dnes, Lidové Noviny also covering Slovakia, the Slovak weekly Týždeñ and the daily Sme. The Slovak case has the methodological disadvantage of a distorted media landscape and most information therefore comes from TI, Freedom House or Czech sources. Self-critical analysis of political elite behaviour is rare, but can happen. See the interview with former Czech Prime Minister Mirek Topolánek in the Czech daily Lidové Noviny on 24 November 2007. 
analysis is the assumption that the highest political levels aim to control independent or executive institutions, like justice or police. I outline the main agents of corruption as well as the intermediaries involved, the politics of the principals, notably the instruments used to influence agencies engaged in anti-corruption as well as the kind of anti-corruption measures proposed according to single government periods.

\section{The non-institutionalization of anti-corruption in the Czech Republic}

\subsection{Politics and corruption during the conservative governments in the $1990 \mathrm{~s}$}

The late 1990s laid the bases for current corruption problems in the Czech Republic. A serious problem has been the influence of politics on the police. From 1989 onwards, the police has been used as a political instrument and tightly connected to the highest political levels. For example, the police covered suspects of political corruption if required by high political representatives and impeded independent inspections. In the mid-1990s, serious cases of corrupt politics surfaced: the Chemapol privatization (Myant 2003, p. 234) and the case of the Berdych gang that had infiltrated the police. In the end, inspectors worked together with criminals for personal gain (Radio Prague 2006b). Later, the Mrázek gang became in this respect, as they succeeded in corrupting the police (Radio Prag 2008; Kmenta 2007, 2008). The criminal influence on investigative authorities had influenced judicial organs as well. One indicator of this is that some preliminary proceedings lasted more than a decade. ${ }^{14}$

The closed-shop mentality of the political and legal elites in the Czech Republic was to become obvious in the late governing era of the conservative party ODS in 1996 and 1997. The refusal to be controlled by independent institutions, such as investigative police and judicial agencies, gave way to quasi-institutionalized corruption - the ODS leaders acted as if they never could lose power.

In the light of scandals, the ODS-led government of the Czech Republic assigned the minister of interior to develop a concept of offensive methods for detecting corruption in the civil service in 1997. In 1998, the conservative government launched the first anti-corruption campaign to deal with fiscal crime and corruption. It was called "Clean Hands". The reactions of the opposition and the media were negative, as the program did not propose new institutions or new regulations to be adopted. ${ }^{15}$ The anti-corruption campaign had been enacted to distract from the scandal-ridden governing of the conservative party ODS, which had become increasingly self-confident and centred on its few leaders from when it had assumed power in 1992 onwards (Kopecký 1995, p. 52).

Additionally, adversaries were accused of being corrupt. Among others, the ODS blamed their coalition partners of corruption: In 1996, the then political party president, Václav Klaus, publicly suspected his political adversaries from the ODA (Civic Demo-

14 In the case of a Kurdish businessman, the proceedings were delayed, witnesses not heard, and defence of the accused Yekta Uzunoglu was not adequate. After 13 years a verdict of not guilty was issued (Radio Prag 2007a).

15 The campaign produced around fifty cases, with the former finance minister being the subject of one of them. It was admitted to be a failure and terminated in early 2000 . 
cratic Alliance) party to have revealed the corruption case around the privatization of the biggest Czech bank in order to spread negative political propaganda against himself and the ODS party (Respekt 2011a). ${ }^{16}$

Until the mid-1990s, corruption had not been of public relevance, but with organized crime leaking into the Czech government, with media coverage and in light of the degrading ODS governing and the upcoming 1998 parliamentary elections attention increased.

Political power elites did not want to propose measure, but had to do so as they faced losing their power. Formally independent anti-corruption police units were set up. The establishment of the Anticorruption Service SPOK and the Office for the Detection of Organized Crime ÚOOZ were initially perceived as serious steps to anti-corruption policy, bBut soon it became obvious that their directors were tied to politics, and therefore those offices had little impact (Gallina 2008, p. 124). ${ }^{17}$ The ODS interior minister, linked to corruption himself, proposed an anti-corruption plan that later proved not to tackle the most urgent problems: political elite corruption and the criminalization of politics. In this ODS governing period politicians established rather useless elite-controlled institutions, and proposed an (ineffective) anti-corruption plan as late as 1998.

\subsection{Opposition agreement period (1998-2002)}

Prime Minister Václav Klaus had created a climate of mutual suspicion on the one hand and of clientelism and corruption on the other hand. ${ }^{18}$ With his late anti-corruption policy and electoral rhetoric he still managed to get significant political support. Due to personal animosities of Klaus, a minority social-democratic ČSSD government headed by Miloš Zeman could assume office, tolerated by the Civic Democratic Party ODS, and both parties agreed to a political ceasefire. ${ }^{19}$ A political opposition would no longer exist, and as a consequence, a corruption climax was reached during this ČSSD government. Its governing period from 1998 to 2002 is considered as the most corrupt so far. As one of the first measures, loyal persons were placed in all important state companies and agencies. ${ }^{20}$ This involved a battle against the newly established anti-corruption agencies,

16 The actual privatization process at first appeared to be relatively free of overt corruption. "In 1994, however, the police arrested the director of the Center for Voucher Privatization, Jaroslav Linzer" (Deegan-Krause 2006, p. 64) - he was accused of having accepted bribes.

17 Even if the Czech Republic received its most favourable CPI rating ever (see annexe).

18 See Idnes.cz (2000) on the (illegal) party financing of the ODS; extensively Tabery (2008) and Kudrna and Volná (2007).

19 As well-known from organized crime, business is most profitable in cases of ceasefire, mutual agreements and the separation of the relevant business branches.

20 Probably the most serious case was put to a Swiss court, the Mostecká uhelná společnost MUS, today's Czech Coal, (http://www.czechcoal.cz/en/index.html) was privatized for a ridiculous amount of 26 million Euros (allegedly Zeman stood behind the deal, see Kudrna and Volná 2007). Swiss procurators confiscated assets worth a couple of billion in Switzerland. The finance ministry and the Prague state prosecution sabotaged investigations and ignored the Swiss charge (Radio Prag 2011b). This provoked a strong Swiss reaction: the stripped money would probably not be returned to the Czech state (NZZ 2012) - a final decision was to be made in autumn 2013. 
independent police, and independent media - notorious cases were the libel suit against the weekly Respekt and the involvement of Miroslav Šlouf, adviser to Miloš Zeman, into politics (Radio Prag 2001; Jordan 2002; Tabery 2008). ${ }^{21}$

A show-case for the unwillingness of the political elite to be controlled by independent agencies was the dismissal of the only successful member of the Czech Anticorruption Service SPOK, Evžen Šrrek, in summer 2000. ${ }^{22}$ He was investigating illegal founding of the social-democratic party. In late 2007, the Czech daily Mladá Fronta Dnes quoted an official from the police headquarters, who said that Evžen Šrrek had been on the verge of uncovering serious fraud in the Czech Savings Bank. Police officials emphasised that Evžen Šrrek was charged on the very same day when he was planning to seize the documents that should have proved the fraud, connections to lobbyists and high politicians. ${ }^{23}$ By these means all the anti-corruption efforts and the work of existing agencies became useless.

At the same time Prime Minister Miloš Zeman publicly expressed his disgust with the anti-corruption service's work. This might be due to the investigations the service led into illicit political party accounts, in particular of the Civic Democratic Party ODS, or due to the investigation into the attempted murder of the ČSSD sponsor Ivan Lhotský. The ousting of Evžen Širek prevented corruption issues from being solved, especially the corruption in the Czech Consolidation Agency ČKA (Spurný 2000). The period also saw the dismissal of the directors of the security service BIS, the National Security Agency or of the Agency against Money Laundering respectively (Kudrna and Volná 2007).

A significant pattern of reaction has been to accuse coalition partners or oppositional politicians of corruption, but this was not the case in the period of institutionalized corruption. Instead, the focus was on independent police services or media that still dared to reveal cases of corruption.

The systemic relevance of corruption became fully evident with compliance on the part of the police, investigative agencies and the judiciary. ${ }^{24}$ Political elites of both governing parties could exercise their powers; political decisions of any kind were made without control. In this period, political power did not want and did not have to control corruption. However, when they went as far as trying to control public television, public protests erupted in late December 2000 (Tabery 2008; Lízal and Kocenda 2001, p. 156). According to observers, the situation calmed down a little, but on a long-term

21 On his (dubious) activities also http://vladneme.cz/?doc=slouf (Accessed 10 Jan 2013).

22 On rather ridiculous grounds: he was accused of cross-checking information on his private computer. The Supreme Court dismissed the charges as late as 2003 (Kudrna and Volná 2007).

23 Former government elites were thought to be involved in his ousting, namely, former Prime Minister Stanislav Gross, then vice president of the Czech Parliament (Kundra and Spurný 2008).

24 For example in the person of the police president Vladislav Husák. He violated the speed limit, donated CZK 10,000 and gave up his driving license for three months. The daily Mladá Fronta Dnes complained that other citizens would have had to pay 22,500 plus would have received a year's ban on driving. The police president was additionally accused that he had warned key suspects ahead of their planned arrest. He had to step down in March 2000. 
scale the protests had little effect, although corruption indices showed worsening Figs. (see annexe). ${ }^{25}$

\subsection{Obstacles to investigation}

The ODS was perceived of being more corrupt than the ČSSD, and due to this, the ČSSD gained power to govern without ODS support. Vladimír Špidla succeeded Zeman and did not continue the governing style of the opposition agreement. But soon, electorates' hope was disappointed, as the ČSSD government continued to be built on corruption and gave rise to several serious scandals. ${ }^{26}$ These governments were not interested in anti-corruption measures, in particular the ČSSD governments of Stanislav Gross (2004-2005) and Jíri Paroubek (2005-2006). Gross was suspected of having connections to Czech's organized crime and had to leave only nine months after his appointment, because media revealed dubious transactions. ${ }^{27}$ However, he never responded to a single case judicially.

Instead, Czech Prime Minister Stanislav Gross had invented another hindrance for the Office for the Detection of Organized Crime ÚOOZ that had been created to combat organized crime. The agency was restricted to only investigating crime, and was instructed to keep away from political corruption. Corruption investigations were transferred to the SPOK, the Anticorruption Service, which did not deal with organized crime, despite the fact that organized crime was inherently connected to political corruption, for example in the case of biological fuel licence tenders (Mladá Fronta Dnes 2006; Spurný 2007d).

The ÚOOZ published its investigation results in May 2006, shortly before the parliamentary elections, despite the political demand to stop corruption-related investigations. Elites had counted on the political dependency of the service. But instead, its director Jan Kubice revealed how criminal structures had infiltrated the state administration and the ČSSD government led by Jiří Paroubek (2005-2006). ${ }^{28}$ The social-democratic party feared losing power and initiated a special investigation into whether this report signified a criminal act. ${ }^{29}$ Jan Kubice received threats on his life and sixteen criminal charges, presumably politically motivated. ${ }^{30}$ Nevertheless, these ÚOOZ reports were ignored at a high political level and additionally even criticized by the judiciary (Radio Prague 2007c).

25 Tabery (2008) offers an in-depth analysis of the whole governing period. The impressive documentary film Vládneme nerušit provides details on government-business connections, corruption scandals and the infiltration of independent agencies (Kudrna and Volná 2007; only in Czech).

26 See http://kmotrdrobek.jex.cz/menu/afery-a-korupce/afery-v-politice (Accessed 15 Oct 2011).

$27 \mathrm{He}$ had to step down because he purchased an expensive luxury flat and financed it with a loan from an unclear source. In September 2007, the Czech daily Mladá Fronta Dnes revealed additionally that he owned a major stake in the energy company Moravia Energo that he could not have purchased from his own income (Mladá Fronta Dnes 2007 and Spurný 2007c).

28 See the so-called Kubice-report under http://zpravakubice.sweb.cz/ (Accessed 10 Oct 2011).

29 Later, it was proved that the accusations were constructed and illegal, but nobody had to take the consequences.

30 Zdeněk Doležel, the former head of the prime minister secretariat of Stanislav Gross and Jiři Paroubek, was even accused of having planned the murder of Jan Kubice. 
The report found that Paroubek, the interior minister and the police president hindered independent police work. It particularly accused social-democratic representatives of impeding investigation in the murder of the controversial businessman František Mrázek, who negotiated the privatization of state enterprises, most notably the sale of the petrochemical giant Unipetrol on behalf and in favour of high ČSSD politicians during the 2000s (Spurný 2006). Such a constellation and the largely uncontrolled operations had been possible because elites had worked as a closed shop which had favoured the access of criminal networks to politics in the 1990s (Radio Prague 2005).

The ÚOOZ from its very beginning of existence had to face the attempt of various social democratic and conservative political networks to exploit the agency for their own political benefits or to close it down (Gallina 2010). Jan Kubice and his team were publicly turned into scapegoats and accused of having failed to meet the obligations of their office. Kubice left in 2008 after losing support from Interior Minister Ivan Langer, and after the police headquarters, dependent on the interior minister, had tightened control of sub-officials - among others they had to report to their superiors every meeting they intended to have. ${ }^{31}$ The Czech police president himself informed the minister on interesting pending cases (Mladá Fronta Dnes 2010). As a consequence, the Czech Office for the Detection of Organized Crime ÚOOZ and the Anticorruption Service SPOK were equipped with new heads that had proved themselves reliable bureaucrats, loyal to the political sphere (Spurný 2008a).

After the period of the minority government, tolerated by the parliamentary opposition, the subsequent social-democratic governments continued to avoid anti-corruption politics: The ČSSD governments ignored the media and actively countered the Kubice report and its authors; but were initially also not made accountable by the public in between or in elections. They accused other colleagues and parties of being corrupt, weakened the ÚOOZ and the SPOK, and influenced the justice and police realm negatively. Here, political elites did not want and in principle also did not have to combat corruption. These governments even fostered corruption. However, they did not manage to fully control the situation - therefore, ÚOOZ and the Kubice report from 2006 could claim that political elites had allowed for a criminalization of the political sphere. Despite this, the Corruption Perception Index (CPI) showed better Czech rankings, while Freedom House rather saw stagnation. In contrast, an elite-oriented analysis shows a clear deterioration of the situation.

\subsection{The Topolánek government: laying the prerequisites for anti-corruption institutions?}

The government in 2007 underlined its will to combat corruption (Radio Prag 2007b; MVČR 2006, and compare with MVČR 2007). Before assuming the office of prime minister, Mirek Topolánek had promised to combat political corruption. But afterwards, he changed his conduct toward the media, the public and party colleagues (Spurný 2010). Political pressure on the ÚOOZ had grown considerably after its accusations that political corruption concerned the ČSSD and ODS equally, mainly during the opposition agree-

31 Additionally, the ÚOOZ was forced not to pay overtime, as the superiors knew very well that the most important informants would not meet during office time. 
ment period. Subsequently, ODS Interior Minister Ivan Langer (in office from 2006 to 2009) was blamed for effectively liquidating the ÚOOZ, after many staff members left ÚOOZ.

Additionally, many groups of the political elite resisted the replacement of the criminal code from socialist times. It stipulated that investigation against politicians could not be opened without proof of the act of handing over money. This helped the former Prime Minister Stanislav Gross to get away without charges for corruption. ${ }^{32}$ The law from 1961 was replaced only in 2008, after numerous delays in parliament, and only because the ruling party had lost its credibility. So elites had not wanted, but were forced to do something. Passing a new Czech criminal code was crucial for the establishment of the intended special court and prosecution office (Spurný 2008b; Freedom House 2008, p. 185). Those institutions would give special anti-corruption police units more institutional backing when confronting corrupt political elite networks. The nearly twenty-year long repression of the new criminal code underlined the fact that political elites had no interest in paving the way for easier combatting against corruption and relevantly for anti-corruption institutions.

Attempts to hinder corruption investigations did not stop after the criminal law come into force. The show case was that of Jiří Čunek, a politician from the Christian and Democratic Union/Czechoslovak People's Party KDU-ČSL. The media accused him of accepting bribes and an investigation was initiated. The responsible prosecutor publicly expressed doubts about the credibility of the principal witness and the state prosecution suspected investigators of manipulating evidence. The investigation was stopped on account of procedural errors. Finally, the case was re-opened and Čunek resigned as regional development minister and vice-prime minister. However, he remained senator and chairman of the KDU-ČSL (Gallina 2010). In November 2007, General Prosecutor Renata Vesecká ordered detailed investigations, but the responsible prosecutor decided to close the corruption proceedings again. Čunek was reintegrated into the government in April 2008 (Schmid 2008; Freedom House 2010, p. 189). Elites did not want to propose measures, in principle they should have had to, but as in many other cases government stability was placed above the corruption question. Just to remind: the period of the "opposition agreement" had been the most notorious.

This case, however, caused a serious split in the state prosecution and revealed the close ties between politics and the judiciary. In May 2008, the displaced first prosecutor of the Jiř́ Čunek case, Zlatuše Andělová, said in a court hearing that the Vice-President of the Supreme Court, Pavel Kučera, and the General Prosecutor, Renata Vesecká, themselves were involved in exerting pressure on her to stop the investigation. Justice Minister Jiří Pospíšil, who had been in office since 2006, refused to dismiss General Prosecutor Vesecká. Prime Minister Mirek Topolánek repeatedly stated that Jiří Čunek could return to office if he cleared his name. At this point, the term "justice mafia" came into use to

32 As above mentioned Stanislav Gross bought a flat with suspicious money, another politician, Jiří Čunek, received social welfare. The KDU-ČSL politician allegedly obtained 18,000 Euros from a real estate agency, and was accused of receiving bribes. Czech television reported in 2008 that he had accumulated three and a half million CZK in his bank account in the mid1990 s, at the same time receiving social benefits. 
denominate political influence on the judiciary (Spurný et al. 2008; Freedom House 2010, p. 189).

The Čunek case showed the growing self-consciousness of the state prosecution, like single state prosecutors gained more self-confidence in spite of a powerful disciplinary board, and the pressure of single ministers.

It was a vicious circle of government-connected political corruption: government stability depended onto whether corrupted politicians remained in office or not. Additional, the Čunek scandal for the first time shed full light on the bargaining methods between political elites and the judicial machinery. ${ }^{33}$ This case was characteristic for the "elites do not want and do not have to" attitude. However, for the first time a serious discussion of practices accepted since 1989 became possible, namely the right of the minister of justice to appoint and to dismiss the general prosecutor.

Nevertheless, Jiř́ Čunek was sacrificed, in order not to endanger the control of judges and state prosecution. In firing one discredited politician, at least the dependence of the justice sphere could be largely retained. As a consequence judicial staff members who were willing to enforce the rule of law were ousted by their own colleagues and the appointment of judges remained a primarily political decision. ${ }^{34}$

In this period, prosecutors had been repeatedly re-assigned to other cases in order to ensure political correctness of the judiciary. Additionally, police presidents regularly informed the ministers on investigations into political corruption. Subversive regulations outweighed anti-corruption politics, for example, the rather artificial difference between political corruption, a task of the anti-corruption task force, and organized crime, an ÚOOZ task. Moreover, it has been criticized that high-ranking officials from the police or other superior units had to give a formal order to start a prosecution (Uhlír 2010; Kundra 2010). This pointed to an urgent need of high politicians to conceal their involvement in suspicious deals. The overall corruption situation was assessed negatively by CPI (degrading) or slightly improved according to Freedom House. In any case, the result of servile judges, state prosecution, and police directors was that the Czech police did not manage to close a single case of the big post-communist corruption scandals in spite of anti-corruption agencies in place.

\subsection{The Nečas government: end of the judicial mafia and...?}

Public pressure through elections could now get more significant, as the established parties had finally totally discredited themselves. The Kubice and Čunek cases revealed the stunning dependence of the judiciary and the independent police units - and the term

33 In most cases, the politicians were successfully influencing important judicial cases in their favour. For example, ČSSD corruption around alternative fuel transactions caused the state losses of millions of CZK. However, the state prosecutor stopped investigation in summer 2007. Political scientist Jan Bureš holds that politicians in positions such as Prime Minister Mirek Topolánek, even if they should have had different attitudes toward corruption, closed themselves in and only had contact with their close collaborators (Lidové Noviny 2007).

34 Or not named, such as the refusal of Czech President Václav Klaus to name Petr Langer judge in spring 2008 - the judge was not named as long as Klaus kept his office until March 2013. Supposedly, the same has been the case in Slovakia. 
"justice mafia" was accepted even by politicians to characterize the situation. The anticorruption topic dominated the parliamentary election campaign in May 2010, and especially TOP09 and VV, the two small protest parties, ran on the anti-corruption ticket, and were elected into parliament.

Now it seemed that there were forces determined to combat corruption. First, the judicial mafia was disempowered. The general prosecutor and his closest collaborators were replaced, ${ }^{35}$ as well as the vice-president of the Supreme Court. A list of judges and prosecutors who had been members of the communist party was published (Radio Prague 2011a).

Jan Kubice, the former upright director of the ÚOOZ was appointed new interior minister, but entered disputes with the new police president Petr Lessy with regard to planned reforms that concerned the police and a specialized anti-corruption agency. ${ }^{36}$ Cooperation between the two was not possible. It was Lessy who was sacked in summer 2012. He had publicly accused a high police office of professional incompetence - a mistake his adversaries had waited for (Kundra 2012; Spurný and Kundra 2012).

The reform in the state prosecution was also pending, notably to disconnect the appointment and the office of the general state prosecutor from politics, and to establish a special agency within the state prosecution to combat organized crime and economic criminality. ${ }^{37}$

Soon, the old game was played again: the first corruption allegations rose against the VV party, and it became evident that the party had mainly been a vehicle to gain political positions in order to achieve economic goals. The well-known National Economic Council to the Government NERV stepped in and published a report to counter the ineffective corruption strategy of the VV party. ${ }^{38} \mathrm{VV}$ Interior Minister Radek John had discredited itself as the vice-minister for the combat against corruption, and left the government after extensive political struggles (Radio Prag 2011b; Novinky.cz 2011).

Nevertheless, Jan Kubice managed to dissolve year-long corruptive networks, for example in the Ministry of Defence where corruption has been an issue since the 1990s (Radio Prag 2010b, 2011d). This culminated in the stripping off immunity of a former Defence Minister in the summer of 2012. ${ }^{39}$

35 The new general prosecutor put himself in a favourable light and accused the former environment minister Pavel Drobil (ODS) of illegal party financing, not without any reason (Radio Prag 2011f).

36 The interior minister is still the superior of the police president and the state prosecution. In an interview with the weekly Respekt (2011b) Jan Kubice outlined the intended reforms (the 2008 proposed reforms had largely not materialized). They should reduce administrative leverage in the police and facilitate the cooperation between the anti-corruption agency SPOK (whose director still was the same one installed in the above mentioned period), the anti-organized crime unit ÚOOZ and the anti-drugs unit.

37 Justice Minister Pospíšil claimed to support the establishment of such agency (Radio Prag 2011f). He had to go in 2012.

38 See http://www.nfpk.cz/_userfiles/soubory/odkazy/nerv-boj-proti-korupcisbornik.pdf (Accessed 05 Oct 2011).

39 Vlasta Parkanová was also vice speaker of parliament. Those networks were supposedly directed by the former Minister of Defence Martin Bartak. Bartak has been a year-long security policy adviser of Petr Nečas. 
Police could pressure for the first time effectively to get search warrants and conducted a crackdown in the national and the Prague state prosecution in order to collect relevant material (Spurný 2011). The pressure resulted in the ousting of the Prague state prosecutor Vlastimil Rampula who was connected to high-profile corruption cases and was regarded as a patron in corrupt relations. ${ }^{40}$ Additionally, the director of the Prague city police was dismissed, and attempts were made to crack the network of police, state prosecution, judges and politicians in the capital. Some independent judiciary structures along with police structures were finally starting to work. The question was whether they would include significant steps towards anti-corruption. In spite of resistance, independent ministers and their collaborators managed to dissolve the justice mafia, to combat criminal networks in the Defence and Environment Ministry (Českapozice 2011).

In this government period more cases have been brought to court than ever, and politicians and functionaries have been sentenced to prison. Most important, there was a test case with the high level politician David Rath, who as first politician ever in the history of the Czech Republic was stripped off immunity in spring 2012 and put into prison. But in this case police had caught him red-handed with a full basket of "dirty" money (Rozhlas 2012; Novinky.cz 2012). As a culmination and because of the growing emancipation of the police and judiciary Prime Minister Nečas had to leave office in June 2013 (Radio Prague 2013a).

The political changes that are taking place in the context of the fall of the Nečas government are not clearly pointing to an anti-corruption direction (Radio Prague 2013b). It is not clear if the newly appointed officials and the institutional drive will be powerful enough and receive constant political support to break up the vicious alliance between politics, leading police administration, state prosecutors and judges. ${ }^{41}$ The Rath case, however, made clear for the first time that a serious prosecution of politicians is possible, and has so far signified a jump to the "politicians want and do combat corruption" level from the very basic level of the Čunek case in which "elites did not want and did not have to combat corruption."

$40 \mathrm{He}$ was also suspected to have stopped investigation on a corruption case related to a former minister of environment. A document of the state prosecution that ordered to stop the prosecution leaked to the public (document 1439, Kundra 2011). His successor became the prosecutor of the Rath case (see underneath), Lenka Bradáčová (Radio Prag 2012). Presumably, corruption networks in the Prague city hall were also backed by him. See leaked documents cited in Prague Post (2012). Notorious corruption cases were for example asset-stripping in the Investment and Post Bank (IPB), and corrupted army tenders; among others the Gripen, Pandur and CASA cases (ČTK 2011a). The Economist (2011) cites three Czech doctoral students that have found that around $14 \%$ of all tenders between 2006 and 2010 had only one bidder, and $67 \%$ of all the procurements were not shown in the public database.

41 Prosecutors pushed bribery allegations of members of parliament - but the outcome was not clear at the stage of writing (Radio Prague 2013b). Another example was presidential conduct. Outgoing President Václav Klaus issued an amnesty law a few weeks after the end of his office in 2012 that also stopped investigation in a dozen of serious corruption cases. For example, the investigation of a judge who was charged with manipulating tenders. 


\section{Possibilities of institutionalizing anti-corruption politics: the case of Slovakia}

\subsection{The era of Vladimír Mečiar (HZDS)}

The above example of the Czech Republic showed that in sum the political elite were not willing to propose a general package of effective anti-corruption measures. Was the Slovak Republic faring any better?

The Slovak political system, from the beginning of the country's political transformation onwards, had been dominated by the criminalization of high-level politics and political-criminal networks, which undermined young and independent democratic institutions. Vladimir Mečiar (1994-1998) and his political party HZDS. The connection between criminal networks and politics was rampant and political processes were criminalized significantly (Mesežnikov et al. 2008, p. 108). Criminalization stemmed from political elite involvement with the former secret service ŠtB, accompanied by the creation of external and internal enemies and "the verbal criminalization" of political opponents (Mesežnikov et al. 2008, p. 102).

Mutual accusations of politicians were typical for the period from 1994 to $1998 .{ }^{42}$ Political representatives were involved in mafia-like criminal acts and "tunnelling", which meant money stripping in the privatization processes. ${ }^{43}$ The overall situation of corruptcriminal networks that dominated Slovak politics and economy created an atmosphere of political apathy in the country. This culminated in the fleeing of the former Chief of the Slovak Security Service SIS Ivan Lexa, who allegedly had organized the abduction of State President Kovač's son Michael. ${ }^{44}$

In many cases during the Mečiar period leading politicians were overtly involved in corruption. Clearly corruption was systemic through a close network of politicians, institutions and organized crime. ${ }^{45}$ For example, with the support of the Mečiar government, Alexander Rezeš ${ }^{46}$ purchased the Eastern Slovak Steelworks (VSŽ), channelled the profit back to other enterprises that were controlled by him, ruined the company within a few years, and finally sold the steelworks to U.S. Steel.

Slovak media reported on a tight network between the Rezeš family and Slovak organized crime. In late 2006, Prime Minister Robert Fico allowed Július Rezeš to become a

42 Notorious were those of Vladimír Mečiar and Ivan Čarnogurský, then vice president of the Slovak National Council.

43 Prime Minister Vladimír Mečiar allegedly paid 41 Million Slovak Crowns for the reconstruction of his house "Elektra" in cash and refused to inform the public on the origins of this amount of money (Vagovič 2011). Besides, this has been also a feature of the political-economic landscape in the Czech Republic.

44 2011, a court asked Kovač to apologize to Lexa. See Vagovič/Hanus (2011).

45 It is no wonder that CPI and Freedom House ratings have been low. Interestingly, the CPI placed the first Dzurinda governments even lower, while Freedom House registered stagnation (see annexe).

46 The Rezeš family (Július and his father Alexander Rezeš) were some of the most prominent actors in the Slovak wild privatizations of the 1990s that culminated in high-scale privatization scandals with huge financial loss for the Slovak state. 
member of the directorate of the Slovak oil company Transpetrol on the recommendation of Vladimír Mečiar (Hospodarské Noviny, 23 April, 2007) ${ }^{47}$ When Mečiar left office in 1998 he issued an amnesty that was applied to Lexa, mafia collaborators and suspicious SIS agents. By this Mečiar hindered the de-criminalization of Slovak politics.

\subsection{From an authoritarian towards a liberal approach}

The rather authoritarian governing of Mečiar had made the corruption-combat question obsolete as there were no forces that could have challenged his reign. In the end, Mečiar was ousted from office, and the electorate with the media pressured for a political change, which could be seen at the 1998 parliamentary elections. In contrast to the HZDS, the SDKÚ Party and its president Mikulaš Dzurinda had promised to establish a national anti-corruption program. Yet, cases of corruption within the government became evident from the beginning and the Prime Minister Dzurinda had to dismiss four ministers. In fact, the legacy of the Mečiar period has been a tight connection between the political, judicial and criminal sphere (Miller 2000, p.49). Some of the most important networks have continued to operate until today. ${ }^{48}$

The façade program "Clean Hands", established in 1995, was followed by a national anti-corruption program approved by the government in June 2000-it prepared the grounds for systemic changes (Zemanovičová and Sičaková 2001; Sičáková-Beblavá et al. 2011, p. 19, 24). The most important measure concerned the introduction of a randomized case management system in the judiciary to prevent the pre-assignment of cases. ${ }^{49}$

The government gave the Ministry of the Interior and the Ministry of Justice the main responsibilities to fight corruption during the first Dzurinda government, which did not prove the best solution as the ministries managed to draft an anti-corruption program, but were not able to establish effective institutions, for example separate courts and prosecution offices (Sičáková 2002). Those ministries had to draft programs, because the pressure on them was high. Despite that, they were presumably deeply involved in corruptive networks; therefore it was a very necessity for them to hinder effective anti-corruption politics.

Corruption was a key issue again in the 2002 national election campaign, and the SDKÚ promised to implement more effective measures. At the end of 2002 the new coalition under Dzurinda established the Anti-Corruption Department at the Government's Office with Ján Hrubala as its head, who had been known before as a civil activist for anticorruption stances. The implementation of the first corruption program had not worked out due to vague descriptions of tasks and a lack of skilled personnel, and presumably through political influence on the concept's nature.

47 In 2005, he impeded that the case could come before the Special Court (ك̌S) in Pezinok, which was established in 2005 to investigate political corruption and political-criminal networks independently (Slovak Spectator 2005).

48 See the "Gorila" scandal of 2011, described underneath.

49 At the same time, the EU suspended pre-accession funding because of corruption (Slovak Spectator 2001). In 2002, several public officials were accused of corruption. The most prominent to leave its office was the transportation minister (Freedom House 2003). Afterwards, the randomized case management system was turned ad absurdum in re-assigning cases by different means (Piussi 2011). 
The corruption program of the second Dzurinda government was rather technical and originated from the Ministry of Justice - therefore it focused on corruption in the justice sphere. In fact, the governing politicians were driven by its minister Daniel Lipšic, who was regarded as a politically independent person aiming at strengthening independent state structures over the power of political elites and criminal elements (Spurný 2007b). Compared to the Czech Republic, here, anti-corruption programs have been directed by the ministers of internal affairs who had less interest in cutting corrupted networks and establishing efficient anti-corruption institutions. ${ }^{50}$

During the second Dzurinda government the Special Court (̌̌S ) and Special Prosecution Office were founded. Attached to them were two special police units on corruption and organized crime, with secret agents at their disposition. This major step was accompanied by intense political struggle over the right to corrupt. The anti-corruption faction succeeded, and despite the strong resistance of the political opposition (HZDS) the new institutions began to work in summer 2005 (Sičáková-Beblavá and Nechala 2006).

The goal of the two institutions was to strengthen democratic political processes in the country. In contrast to ordinary Slovak judges, the judges of the Special Court underwent screening, like a screening for collaboration with or a membership in the secret police, and were responsible to the Supreme Court of the country. Its founding fathers envisaged a special, independent justice structure to meet high political corruption and to place a counter-weight that could confront the corrupted Slovak justice system. ${ }^{51}$ The Special Court conducts an investigation when members of parliament, judges, or civil servants are suspected of criminal acts and corruption, and investigates organized crime.

As of December 2006, almost 200 cases related to Vladimír Mečiar and his entourage came before the court, of which $70 \%$ were brought to a decision. ${ }^{52}$ The Special Court proved its ability and willingness to decide independently and relatively quickly upon longlasting corruption cases. Some weak points also existed. The right of the Supreme Court of Slovakia to annul verdicts has been criticized distinctively. ${ }^{53}$ As several of its politicians have been the object of court investigations, SNS and HZDS promised to shut down the court in their party programs (Sičáková-Beblavá and Nechala 2006; Šipoš et al. 2010). ${ }^{54}$

50 See for example the strategy presented by the former Minister of Interior John: http://www. mvcr.cz/mvcren/article/new-anti-corruption-strategy-introduced.aspx (Accessed 01 Oct 2011).

51 The establishment of the independent institutions did not solve the problem of a corrupted justice system in Slovakia (Šimecka 2011a).

52 For example, the case of the bankrupt Devín banka that involved several murders and disappearances. On 10 January 2007, the Special Court handed down one of its most significant decisions. Three former managers of bankrupt investment companies Horizont Slovakia and BMG Invest were sentenced to between seven and eleven and a half years for embezzlement.

53 The Majský case has been an example. Jozef Majský was condemned for twelve years in April 2007 for heading a criminal group. The Special Court faced a revision of its verdict on the grounds of formal irregularities. The case was given back to the Special Court. In the end, Jozef Majský succeeded with a complaint in front of the Supreme Court that annulled the previous rulings and set him free (Javůrek 2007).

54 In the period of the 1990s some of those politicians turned surprisingly rich during the privatization of large enterprises. 
This became especially obvious right after the elections in 2006, when former communist judge, and new Minister of Justice Štefan Harabín (HZDS), ${ }^{55}$ an outstanding critic of those structures, presented a draft law, proposing to abolish the Special Court and Special Prosecution Office. He intended to give powers back to local courts with appeal possibilities in front of (corrupted) regional courts. Also, former State President Ivan Gasparovič, one of the closest intimates of Vladimír Mečiar in the 1990s, argued that special courts are not necessary and that the regular courts were sufficient for criminal prosecution (The Slovak Spectator 2006). So, SNS and HZDS quite openly presented their disgust of anticorruption institutions.

The then President of the Special Court, Igor Králik, emphasised that both HZDS and SNS were against the court because it worked independently. The independence of the court was hard to accept for those politicians who, according to him, were used to the methods of the old regime which included bribes and threats and the belief that a court had to be subordinated to politics and to decide in line with political requirements (Schmid 2006).

The country improved its rating in the Corruption Perception Index from 57 (2004) to 49 (2007). ${ }^{56}$ The anti-corruption effort was significant under Dzurinda, and the government was determined to propose measures and in fact adopted effective measures. Still there were corruption scandals and laws that were approved were poorly applied, such as the 2004 law on conflicts of interests that had been a serious issue in the 2002 national elections (Freedom House 2006). ${ }^{57}$ Single, independent actors drove the process, notably the prime minister and his justice minister. In contrary, most of the political elites would have neither proposed nor adopted measures, and instead seemingly would have preferred a politically dependent justice and police agency. ${ }^{58}$

\subsection{Anti-corruption: reset during the Robert Fico period}

After two terms Dzurinda had to pass power to the opposition, and in 2006 a coalition of Smer, SNS, and HZDS took over power. These parties had a significant percentage of anti-reformist members. The new government did not feature anti-corruption measures in its program and no official government strategy existed (Bútora et al. 2009, p.11; Sičáková-Beblavá et al. 2011, p. 21).

This has been in line with political elites who do not allow politically independent institutions and who lobby against the special court, because they had been deeply involved in the issue. Therefore, it is of no surprise that there were various efforts to strip the special court of its powers when a new government coalition of the anti-court parties won the elections. A decision of Slovak Prime Minister Robert Fico at the beginning of 2007 changed its status and reduced additional wages of the judges.

55 According to "Gorila" he was placed in this function to find incriminating evidence against Lipšic. This would additionally underline his role as independent actor.

56 The Czech Republic improved from 51 (2004) to 41 (2007) http://archive.transparency.org/ policy_research/surveys_indices/cpi/2004, http://archive.transparency.org/policy_research/surveys_indices/cpi/2007 (Accessed 01 Oct 2011).

57 Concerning corruption perception ratings (CPI) and Freedom House, the situation improved considerably from 3.7 to 4.7 and from 3.75 to 3.0 (see annexe).

58 Most of the suspicions were confirmed the context of the "Gorila" case, see below. 
As Anna Vitteková, state secretary of the Ministry of Justice, stated in November 2006: "Inspired by the experience from abroad (the Czech Republic, in particular) the struggle with corruption will focus on prevention, which was neglected in past years, instead of repression" (ČTK 2007). ${ }^{59}$

In the related field of transitional justice, it is worth mentioning the case of the independent Nation's Memory Institute ÚPN established in 2002. The institute guards files of the interior ministry, defence ministry, justice ministry, and the Slovak Information Service SIS. The files concern activities and lists of members of the communist secret police ŠtB. Its goal is to gradually publish a register of communist secret police officials. ${ }^{60}$ The government of Robert Fico tried to subordinate the institute to political structures and replaced independent members of the director's board with politically loyal persons. The efforts of politicizing the ÚPN were of particular importance because the Nation's Memory Institute was the only Slovak institution publishing ŠtB registers and therefore of high importance. This has some relevance for anti-corruption policy, as previous ŠtB collaborators had transferred to the SIS and still exerted a lot of influence during the Mečiar era through supporting Mečiar's illegal activities. Consequently, Mečiar had abolished the lustration law after Slovak independence in 1993. After the take-over of Robert Fico, loyalists were placed in strategic positions in the SIS. ${ }^{61}$

In April 2008, the SNS came up with a proposal to abolish the ÚPN after information on illegal deeds of young Ján Slota, the head of the nationalist SNS party, leaked to the press (Javưrek 2008). Also because of corrupted tenders, Transparency International Slovakia assessed the anti-corruption effects of this government as negative (TI Slovakia 2010).

Concerning the work of the Special Court, it faced restructuring, but the number judgements delivered was stable between 2006 and 2010. This also concerns the number of detected cases, accused and sentenced persons. The overwhelming majority of those cases came before the Special Court. ${ }^{62}$

TI terminated the cooperation with the government due to its passivity. Mesežnikov et al. (2009, p. 495) even spoke of a "significant decline" in anti-corruption activities. Moreover, Robert Fico had repeatedly defended political clientelism and attacked NGOs. He also presented a draft law to restrict media freedom (Freedom House 2008). During his term as Prime Minister, Robert Fico had created the image of an aggressive media landscape in Slovakia that was spreading false information and trying to impede the ruling elites. This strategy helped stop the anti-corruption policy and fostered a restrictive

59 Interestingly, the Czech Republic itself was preparing the ground for a Slovak-inspired battle against corruption with a special court and prosecution, attached special police units and secret agents, and the institution of a principal witness.

60 It released the names of former collaborators and agents in June 2007, and made the archives accessible through the internet.

61 Examples in the "Gorila" file posted under www.gorilafile.wordpress.com. The original "Gorila" file is for example found under: http://pastebin.com/Vqgb77Qz (Accessed 10 Jan 2013).

62 Sentenced: 112, 168, 130, 164, 167 for 2006-2010. See table 3 in Sičáková-Beblavá et al. (2011, p.3). 
media law (Gehring and Thanei 2010), as the media remained rather critical towards the political elites. ${ }^{63}$

The performance of the Fico government showed similarities to the later ČSSD governments in the Czech Republic with respect to its anti-corruption passivity. Robert Fico and his entourage did not want to combat corruption, ${ }^{64}$ and turned to a confrontational strategy to actively hinder the new anti-corruption institutions from working. They tried to influence the justice and police realm and to conceal corruption, even through a restrictive media law. ${ }^{65}$

\subsection{Turn from the Fico government to Iveta Radičová}

The parliamentary elections of June 2010 brought two surprises to many observers: the Smer party of Robert Fico won the elections despite the relevance of corruption. But, oppositional centre-right wing parties were able to form a government. ${ }^{66}$

The significant criminalization of politics under Mečiar had enabled the creation of a Specialized State Prosecution Office for the Fight against Corruption and a Special Court during the Dzurinda government. Additionally, parliament had passed several important laws. The Fico period was a setback, however.

Iveta Radičová, the new head of government, managed to drive anti-corruption politics forward again. In this context Sičáková-Beblavá et al. (2011, p. 12) offer an analysis of the word "corruption" in government policy statements: the Radičová government had it 20 times, Fico 9 times, the Dzurinda governments 23 and 12 times respectively.

Since January 2011, all state biddings have had to be published on the internet, which means that all Slovak public administration institutions are obliged to publish any contracts involving allocation of state or public resources (The Slovak Spectator 2010b; Šimečka 2011b). In summer 2011, Radičová presented a draft document on anticorruption - scheduled to be completed in November. Unfortunately, her government was brought down in October 2011 ostensibly because of the EU bailout fund, although domestic issues also seemed to play an important role (Prague Post 2011).

Daniel Lipšic, Minister of Justice under Mikulaš Dzurinda, had returned into government as minister of internal affairs in 2010. He proceeded with the anti-corruption issue, placed emphasis on independent, professional staff members, reformed anti-corruption offices and courts and fostered regulations on principal witnesses' courts (The Slovak Spectator 2008) - at that time there already had been efforts to induce investigations into the "Gorila" tape transcript which proved systemic corruption. Leading politicians regu-

63 For example current Czech President Zeman characterized Czech journalists as "the dumbest creation on earth;" translated from and quoted in Kudrna and Volná (2007).

64 One of the major scandals concerned the Slovak Land Fund - Robert Fico hat to dismiss the deputy director of the fund and the agriculture minister. A major issue was EU fund corruption: it concerned public procurement at the construction ministry overseen by a Slovak National Party (SNS) minister. Freedom House and the government underlined that those branches, including courts (and the health sector) have been the most affected (Prague Post 2011). Besides, the Czech Republic faced an EU fund freeze in 2012.

65 On the usual ratings Fico was even better rated in his first years (see annexe).

66 For an overview of the campaign see Haughton et al. 2011. 
larly met with important businessmen (e.g. of the main investment group of the country Penta) in an apartment to plan faked privatizations, the "tunnelling" of assets, illegal party financing, and the bribing of politicians or judges in general. ${ }^{67}$

Still, there was no overall party consensus on the need of anti-corruption, and mainly the HZDS-party continued to obstruct anti-corruption politics, for instance with respect to the new general procurator (SME 2010) ${ }^{68}$ Also during the Radičová government politicians from HZDS, SDKÚ-DS and SNS accused each other of being corrupt, and Smer and SNS obstructed anti-corruption legislation. ${ }^{69}$

\subsection{Again Fico}

The fight against corruption was a crucial topic in the March 2012 election campaign, especially as the tape transcript, "Gorila", had leaked at the end of 2011.

But again, elections won, reality is a different one: The government has not developed any anti-corruption activities, placed a loyal general prosecutor, police president and purged police (Transparency International Slovakia 2012 compare with Kurian 2012). The new police president Jaroslav Spišiak refused any information on the investigation in "Gorila"-linked corruption cases in order "not to endanger investigations" (Piussi 2011). The former Justice Minister Harabín was named president of the Justice Council and filled the Supreme Court with his loyalists. The Council additionally opened various disciplinary proceedings against independent judges and suspended them from office, and brought justice reforms to a standstill. In July 2013, a new state prosecutor was named - according to the political opposition the general prosecution was brought under control of the SMER party (SME 2013b). The judge Peter Paluda claimed that politicians had overtaken the justice sphere. ${ }^{70}$ To be sure, the media and indpendent investigators were blamed for the situ-

67 SIS agents had installed a legal wire tape between 2005/2006, and requested their superiors to act. Then police president Tibor Gašpar (featuring in the transcripts in connection to Penta) allegedly said there was no chance of investigation. After 2010 they wrote to Lipšic, and made another effort to push the case, the report was handed in again (it had been lost), but the investigation team was harassed and closed down. Nicolson further describes the general reluctance to "go into it" under every government. See Tom Nicholson in Piussi (2011), Nicholson (2012), and Piussi (2010-2012).

68 Allegedly corrupt behaviour of highly-positioned employees has taken place in the Office for the Fight against Corruption, and some officials have been accused of having accepted bribes in order to stop investigations (The Slovak Spectator 2010a).

69 Transparency International Slovakia found that there was some improvement. http://www.transparency.sk/sk/analyza-hodnotenie/ (Accessed 20 Oct 2012).

70 A judge was alleged to cover up cases and co-responsible for the death of a co-judge (Piussi 2011). Consequently, she filed a criminal complaint for her coverage in Piussi (2011). Prosecution was stopped after international protests in January 2013 (The Slovak Spectator 2013). In the course of disciplinary proceedings several judges were removed, among them Juraj Majchrák, the vice-chair of the Slovak Supreme Court, and sharpest critic of Harabín, who was driven to suicide. Harabín was additionally accused of having close contacts to an Albanian drug cartel boss. The issue was discussed 2008 in parliament at the time Harabín was justice minister. The general prosecutor confirmed the authenticity of the tapes - the result was that 
ation. Štefan Harabín spoke of media libel in regard to politics and himself filed libel suits (SME 2013a). This gives a rather grim outlook for the further combat against corruption.

\section{Conclusion}

This article on the politics of anti-corruption in the Czech Republic and Slovakia in the last twenty years argues that programs against corruption mostly were not well-equipped or of a preventive nature. There were some exceptions, such as the repressive anti-corruption efforts of the liberal Dzurinda government in Slovakia and the ousting of corrupted judges and politicians during the Czech Nečas government.

Sičáková-Beblavá et al. (2011, p. 16) summarize the situation in Slovakia as following: Under Mečiar corruption was not a big topic, and if there were measures, they were preventive. The first Dzurinda government gave more attention to the topic and offered a combination between preventive and repressive instruments. One of the priorities of the second Dzurinda was the corruption problem, measures were preventive and repressive. Under Fico the relevance declined with preference for repressive instruments. The Radičová government again turned to the second Dzurinda government methods, even more pronounced. While the following Fico government returned to his previous politics. $^{71}$ The Nečas government had theoretically paved the way for an emancipation of the state prosecution and police. It would depend on future governments how anti-corruption politics would evolve. For the Czech Republic we can state that no outspoken reform periods existed, instruments focused on repression; however the Nečas government theoretically paved the way for an emancipation of the state prosecution and police. It would depend on future governments how anti-corruption politics would evolve.

Even if anti-corruption measures have been implemented, they often have been weakened by concurrent politicians as in the case of the Czech SPOK during the Miloš Zeman government period, and the special court and prosecution office in Slovakia during Fico governments. Resistance against effective anti-corruption politics has been a dominant attitude.

Intermediaries were installed to materialize corruption. They took the form of superiors or directors who acted in a subversive way, adopt hindering regulations, and distribute posts and bribes. In certain periods, the relationships were highly criminalized, especially during the Mečiar period in Slovakia, and the period of the coalition agreement between the ODS and the CSSD in the Czech Republic. Those were periods without accountability. But even if there was some accountability in the form of media or public control, criminal or corruptive relationships remained to be important. Cases in both the Czech Republic and Slovakia were for example that personal advisers to the prime minister who were engaged in major corruption. A notorious example for the Czech Republic has been Miroslav Šlouf, adviser to Miloš Zeman.

Harabín was granted compensation for the damages on his reputation. Details in Piussi (2011) and Šimečka (2012).

71 Sičáková-Beblavá et al. (2011, p. 28) also offer a list of corruption cases broken down to political parties and ministries. This paper is the most comprehensive on Slovakian anti-corruption politics. 
Several governments, like the ČSSD governments in the Czech Republic and Robert Fico in Slovakia, have not been willing to propose further measures and have combated against already established institutions engaged in anti-corruption. The recent measures in the Slovak justice system give little hope for the future. Also, institutions were often proposed in times of political tensions, as shown by those of the ODS in the late 1990s or before the predicted breakdown of the ČSSD governments in the late 2000s.

Developments in the Czech Republic and Slovakia often featured oppositional elites proposing measures which they abandoned once they assumed office. Governing elites, in contrast offered measures when public pressure was high but otherwise avoided the issue, downgraded their plans or imposed regulation that would be of no further help. The degree of corruption has varied until today, but is considerably high.

In this post-transformative constellation, individual actors are of high importance, especially the respective prime ministers and the ministers of the interior and the ministers of justice. A second precondition for effective anti-corruption measures is the selection of independent and professional staff members in the offices of the police president, the state prosecution, especially the general prosecutor, the directors of anti-corruption agencies as well as judges of special or relevant courts.

The main problems in both countries have been the politicization of investigative agencies, dependent police presidents as well as state prosecutors and judges who close their eyes at suspicious tenders, privatizations and other incidents. The willingness to apply corruption-supportive measures has often been higher than the willingness to propose effective anti-corruption programs in both countries. Some measures during the Nečas period in the Czech Republic were undertaken without a program, but had been driven by single powerful actors, the interior and justice ministers and some state prosecutors.

In fact, there has been only one (more or less) effective, repressive program drafted by the Dzurinda government in Slovakia. Unfortunately, the "Gorila" tape transcription that revealed systemic political corruption concerned the Dzurinda governing period which gave the impression that his governments were especially corrupted. However, the systemic corruption revealed was not an invention of Dzurinda: the Vladimir Mečiar (1994-1998) reign had laid the basis for this system that continues to work until today. The (deliberatley?) leaked transcript were published at the worst point possible - the Radičová government had to go, and it was no wonder that Robert Fico won the elections who did not figure prominently in the transcript.

The politicization of anti-corruption measures has been a crucial problem-the more cases a given government presents, the more this creates the impression that this government is especially corrupted, this was the main problem of the Nečas Czech government which for a majority of the population appeared far more corrupted than previous governments.

A rather grim insight of this analysis could therefore be that the predominant elite strategy was to continue with their "business", and to ignore the corruption problem unless significant public indignation or pressure from the political opposition emerged. It has not been the case that political power elites as a whole wanted, proposed and enforced effective measures.

This article could only present a fragmented picture of (anti-)corruption politics, and highlight the most important issues. It contrasted qualitative evaluations with selected quantitative findings. While comparing the qualitative insights of this paper with index 
evaluations by Freedom House or Transparency International it is maybe not too pretentious to state that quantitative measures could not analyse in detail why political elites foster or oppose anti-corruption measure, to which networks they belong and which political loyalties they follow. Nevertheless, further in-depth investigation is necessary and it would be desirable to identify political power networks more clearly, and to follow their long-term development.

The goal of this article was to contribute to research on the relationship between political elites and corruption, and to depict underlying forces of the corruption problem in post-transformation societies. It has been shown that little willingness might have to do with the political elite's unwillingness to submit to a system based on rule of law. This could be overcome through individual actors who manage to evoke a knock-on effect pushing the establishment of a firm regulative framework that could succeed in adapting the political elite's needs to a formal democratic system (Tables 1 and 2). 


\section{Annexure}

Table 1: Slovak Prime Ministers and State Presidents (Slovak Republic)

\begin{tabular}{|c|c|c|c|c|c|}
\hline \multicolumn{6}{|c|}{ Prime Ministers (from 1992 onward) } \\
\hline Beginning of office & End of office & Prime Minister & Government & $\begin{array}{l}\text { CPI } \\
\text { Corruption }\end{array}$ & $\begin{array}{l}\text { Freedom } \\
\text { House }\end{array}$ \\
\hline (24 June 1992) & 15 March 1994 & $\begin{array}{l}\text { Vladimír } \\
\text { Mečiar (HZDS) }\end{array}$ & HZDS, SNS & & \\
\hline 16 March 1994 & 13 December 1994 & $\begin{array}{l}\text { Jozef Moravčík } \\
\text { (DEÚS) }\end{array}$ & $\begin{array}{l}\text { Provisional govern- } \\
\text { ment (V. Mečiar } \\
\text { ousted out of office) }\end{array}$ & & \\
\hline 13 December 1994 & 30 October 1998 & $\begin{array}{l}\text { Vladimír } \\
\text { Mečiar (HZDS) }\end{array}$ & HZDS, SNS, ZRS & $3.9(1998)$ & $3.75(1998)$ \\
\hline 30 October 1998 & 15 October 2002 & $\begin{array}{l}\text { Mikuláš } \\
\text { Dzurinda } \\
\text { (SDK/SDKÚ) }\end{array}$ & SDKÚ, MKP & $\begin{array}{l}3.7,3.5 \\
3.7,3.7 \\
(1999-2002)\end{array}$ & $\begin{array}{l}3.75,3.75 \\
3.75,3.25 \\
(1999-2002)\end{array}$ \\
\hline 16 October 2002 & 4 July 2006 & $\begin{array}{l}\text { Mikuláš } \\
\text { Dzurinda } \\
\text { (SDKÚ/ } \\
\text { SDKÚ-DS) }\end{array}$ & $\begin{array}{l}\text { SDKÚ/SDKÚ-DS, } \\
\text { MKP, KDH }\end{array}$ & $\begin{array}{l}3.7,4.0, \\
4.3,4.7 \\
(2003-2006)\end{array}$ & $\begin{array}{l}3.25,3.25 \\
3.0,3.0 \\
(2003-2006)\end{array}$ \\
\hline 4 July 2006 & 8 July 2010 & $\begin{array}{l}\text { Robert Fico } \\
\text { (Smer) }\end{array}$ & Smer, SNS, HZDS & $\begin{array}{l}4.9,5.0 \\
4.5,4.3 \\
(2007-2010)\end{array}$ & $\begin{array}{l}3.25,3.25 \\
3.25,3.75 \\
(2007-2010)\end{array}$ \\
\hline 8 July 2010 & 4 April 2012 & $\begin{array}{l}\text { Iveta Radičová } \\
\text { (SDKÚ-DS) }\end{array}$ & $\begin{array}{l}\text { SDKÚ-DS, SNS, } \\
\text { KDH, Most-Híd }\end{array}$ & $4(2011)$ & $\begin{array}{l}3.50(2011 \text { and } \\
2012)\end{array}$ \\
\hline 4 April 2012 & & $\begin{array}{l}\text { Robert Fico } \\
\text { (Smer) }\end{array}$ & Smer & & \\
\hline
\end{tabular}

Source: http://www.vlada.gov.sk/7366/historia-vlad-slovenskej-republiky.php?menu=1243; CPI Scale: 10 is the best score, tables see under www.transparency.org and Sičáková-Beblavá et al. (2011: 4). They state that the best time for Slovakia was between 2003 and 2007. For Freedom House 1 is the best scoring, see under http://www.freedomhouse.org/report/nations-transit/2012/slovakia. For the Corruption Perceptions Index: http://www.transparency.org/research/cpi/overview

State Presidents

\begin{tabular}{|c|c|c|c|}
\hline Beginning of office & End of office & President & Political party \\
\hline 1 January 1993 & 2 March 1993 & $\begin{array}{l}\text { Vladimír Mečiar prime minister acting as } \\
\text { president) }\end{array}$ & HZDS \\
\hline 2 March 1993 & 14 July 1998 & Michal Kováč & HZDS \\
\hline 14 July 1998 & 30 October 1998 & $\begin{array}{l}\text { Ivan Gašparovič (speaker of parliament) prime } \\
\text { minister acting as president—-parliament was un- } \\
\text { able to choose president }\end{array}$ & Non-partisan \\
\hline 30 October 1998 & 15 June 1999 & $\begin{array}{l}\text { Jozef Migaš (speaker of Parliament) and Prime } \\
\text { Minister Mikuláš Dzurinda acting as President- } \\
\text { Parliament was unable to choose a president }\end{array}$ & \\
\hline 15 June 1999 & 15 June 2004 & Rudolf Schuster & Non-partisan \\
\hline 15 June 2004 & $\begin{array}{l}\text { Re-elected } 21 \\
\text { March } 2009\end{array}$ & Ivan Gašparovič & HZD \\
\hline
\end{tabular}

Source: http://www.prezident.sk/ 
Table 2: Czech Prime Ministers and State Presidents (Czech Republic)

\begin{tabular}{|c|c|c|c|c|c|}
\hline \multicolumn{6}{|l|}{ Prime Ministers } \\
\hline Beginning of offic & End of office & $\begin{array}{l}\text { Prime } \\
\text { Minister }\end{array}$ & Government & $\begin{array}{l}\text { CPI } \\
\text { Corruption }\end{array}$ & $\begin{array}{l}\text { Freedom } \\
\text { House }\end{array}$ \\
\hline (2 July 1992) & 4 July 1996 & $\begin{array}{l}\text { Václav Klaus } \\
\text { (ODS) }\end{array}$ & ODS (-KDS) & & \\
\hline 4 July 1996 & 2 January 1998 & $\begin{array}{l}\text { Václav Klaus } \\
\text { (ODS) }\end{array}$ & $\begin{array}{l}\text { ODS, ODA, } \\
\text { KDU-ČSL }\end{array}$ & $5.37(1996)$ & \\
\hline 2 January 1998 & 17 July 1998 & $\begin{array}{l}\text { Josef } \\
\text { Tošovský }\end{array}$ & $\begin{array}{l}\text { ODS, ODA, } \\
\text { KDU-ČSL }\end{array}$ & $4.8(1998)$ & $3.25(1998)$ \\
\hline 22 July 1998 & 12 July 2002 & $\begin{array}{l}\text { Miloš Zeman } \\
\text { (̌̌SSD) }\end{array}$ & ČSSD (ODS) & $\begin{array}{l}4.6,4.3 \\
3.9,3.7 \\
(1999-2002)\end{array}$ & $\begin{array}{l}3.75,3.75 \\
3.75,3.50 \\
(1999-2002)\end{array}$ \\
\hline 15 July 2002 & 4 August 2004 & $\begin{array}{l}\text { Vladimír } \\
\text { Špidla } \\
\text { (ČSSD) }\end{array}$ & $\begin{array}{l}\text { ČSSD, } \\
\text { KDU-ČSL, } \\
\text { US-DEU }\end{array}$ & $\begin{array}{l}3.9,4.2 \\
(2003-2004)\end{array}$ & $\begin{array}{l}3.50,3.50 \\
(2003-2004)\end{array}$ \\
\hline 4 August 2004 & 25 April 2005 & $\begin{array}{l}\text { Stanislav } \\
\text { Gross } \\
\text { (ČSSD) }\end{array}$ & $\begin{array}{l}\text { ČSSD, } \\
\text { KDU-ČSL, } \\
\text { US-DEU }\end{array}$ & $4.3(2005)$ & $3.50(2005)$ \\
\hline 25 April 2005 & 4 September 2006 & $\begin{array}{l}\text { Jiř̀ Paroubek } \\
\text { (ČSSD) }\end{array}$ & $\begin{array}{l}\text { ČSSD, } \\
\text { KDU-ČSL, } \\
\text { US-DEU }\end{array}$ & $\begin{array}{l}4.3,4.8 \\
(2005-2006)\end{array}$ & $\begin{array}{l}3.50 \\
(2005-2006)\end{array}$ \\
\hline 4 September 2006 & 9 January 2007 & $\begin{array}{l}\text { Mirek Topo- } \\
\text { lánek (ODS) }\end{array}$ & $\begin{array}{l}\text { ODS and } \\
\text { non-partisans }\end{array}$ & $\begin{array}{l}4.8,5.2 \\
(2006-2007)\end{array}$ & $\begin{array}{l}3.50,3.25 \\
(2006-2007)\end{array}$ \\
\hline 9 January 2007 & 26 March 2009 & $\begin{array}{l}\text { Mirek Topo- } \\
\text { lánek (ODS) }\end{array}$ & $\begin{array}{l}\text { ODS, KDU- } \\
\text { ČSL, SZ }\end{array}$ & $\begin{array}{l}5.2,4.9, \\
(2008-2009)\end{array}$ & $\begin{array}{l}3.25 \\
(2008-2009)\end{array}$ \\
\hline 8 May 2009 & 13 July 2010 & Jan Fischer & $\begin{array}{l}\text { Provisional } \\
\text { government }\end{array}$ & $4.6(2010)$ & $3.25(2010)$ \\
\hline 13 July 2010 & 10 July 2013 & Petr Nečas & $\begin{array}{l}\text { ODS, LIDEM } \\
\text { (former VV), } \\
\text { TOP09 }\end{array}$ & $4.4(2011)$ & $\begin{array}{l}3.25 \\
(2011-2012)\end{array}$ \\
\hline
\end{tabular}

Source: http://www.vlada.cz/; CPI Scale: 10 is the best scoring, tables see under www.transparency. org and Sičáková-Beblavá et al. (2011: 4). For Freedom House 1 is the best score, see under www. freedomhouse.org. As we can see in this table, Czech governments have been far more unstableand the relation to corruption remains unclear. For the Corruption Perceptions Index: http://www. transparency.org/research/cpi/overview

State Presidents

\begin{tabular}{|c|c|c|c|}
\hline Beginning of office & End of office & President & Political party \\
\hline 2 February 1993 & 2 February 2003 & Václav Havel & Non-partisan \\
\hline 7 March 2003 & 7 March 2013 & Václav Klaus & ODS \\
\hline 8 March 2013 & & Miloš Zeman & SPOZ \\
\hline
\end{tabular}

Source: http://www.hrad.cz/cs/prezident-cr/soucasny-prezident-cr-milos-zeman/zivotopis.shtml 


\section{References}

Ágh, Attila 1998. The Politics of Central Europe. London: Sage.

Arvind, K. Jain ed. 2001. The Political Economy of Corruption. London: Routledge.

Best, Heinrich, and Ulrike Becker, eds. 1997. Elites in Transition: Elite Research in Central and Eastern Europe. Opladen: Leske und Budrich.

Bielasiak, Jack. 2005. Party Competition in Emerging Democracies: Representation and Effectiveness in Post-Communism and Beyond. Democratization 12 (3): 331-356.

Bútora, Martin, Miroslav Kollár, and Grigorij Mesežnikov, eds. 2010. Slovensko 2009. Súhrnná správa o stave spoločnosti a trendoch na rok 2010. Bratislava: Institút pre verejné otázky.

Bútora, Martin, Grigorij Mesežnikov, and Miroslav Kollár, eds. 2009. Slovakia 2008. Trend in Quality of Democracy. Bratislava: IVO.

Českapozice. 2011. Prague prosecutor's office continues purge over MUS. http://www.ceskapozice.cz/en/news/politics-policy/prague-prosecutor $\% \mathrm{E} 2 \% 80 \% 99 \mathrm{~s}-$-office-continues-purgeover-mus. Accessed 29 Nov 2012.

Česká televize. 2013. Šlouf je zpátky, Zeman to ještě nepřiznal. http://www.ceskatelevize.cz/ct24/ domaci/212572-slouf-je-zpatky-zeman-to-jeste-nepriznal. Accessed 10 Feb 2013.

ČTK. 2007. Slovak Special Court gets reprieve. 15.01.07.

ČTK. 2011a. Justice Minister sacks high state attorney Rampula. 25.07.11.

ČTK. 2011b. Czechs may have lost CZK 8 billion in privatisation fraud. 21.11.11.

CVVM. 2011. Miněni veřejnosti o korupci mezi veřejnými predstaviteli a v jednotlivých oblastech. Praha: Centrum pro výzkum veřejného mínění Sociologický ústav AV ČR.

Deegan-Krause, Kevin. 2009. Toward a More Useful Conceptualization of Populism. Types and Degrees of Populist Appeals in the Case of Slovakia. Politics and Policy 37 (4): 821-841.

Deegan-Krause, Kevin. 2006. Elected Affinities: Democracy and Party Competition in Slovakia and the Czech Republic. Stanford: Stanford University Press.

Della Porta, Donatella, and Alberto Vannucci. 1999. Corrupt Exchanges: Actors, Resources, and Mechanisms of Political Corruption. New York: de Gruyter.

Diamond, Larry. 1999. Developing Democracy: Toward Consolidation. Baltimore: Johns Hopkins University Press.

EBRD. 1999. Transition Report. London: European Bank for Reconstruction and Development.

European Commission. 2013. The EU Justice Scoreboard. A Tool to Promote Effective Justice and Growth. http://ec.europa.eu/justice/effective-justice/files/justice_scoreboard_communication_en.pdf. Accessed 20 Jun 2013.

Freedom House Press Release. 2008. Slovakia's Draft Press Law Risks Curtailing Media Freedom. 31.01.08. http://www.freedomhouse.org/article/slovakias-draft-press-law-risks-curtailingmedia-freedom. Accessed 15 Nov 2011.

Freedom House. 2006. Nations in Transit. http://www.freedomhouse.org/report-types/nations-transit. Accessed 15 Nov 2011.

Freedom House. 2008. Nations in Transit. http://www.freedomhouse.org/report-types/nations-transit. Accessed 15 Nov 2011.

Freedom House. 2009. Nations in Transit. Overview Essay. http://www.freedomhouse.org/report/ nations-transit-2009/overview-essay. Accessed 15 Nov 2011.

Freedom House. 2010. Nations in Transit. http://www.freedomhouse.org/report-types/nations-transit. Accessed 15 Nov 2011.

Freedom House. 2012. Nations in Transit. http://www.freedomhouse.org/report-types/nations-transit. Accessed 15 Mar 2013.

Gallina, Nicole. 2008. Political Elites in East Central Europe: Paving the Way for Negative Europeanisation? Leverkusen: Budrich UniPress.

Gallina, Nicole. 2010. Informality Reigns the Country: The Example of the Czech Republic. Paper presented at the Swiss Conference "Informal Power and Practices," Fribourg, 18 November. 
Gehring, Hubert, and Christoph Thanei. 2010. Länderbericht Slowakei: Machtwechsel in Griffweite. Sankt Augustin: Konrad-Adenauer-Stiftung.

GfK. 1999. Korupční klima v CR 2. Internal Report No. 40/151. Prague: GfK.

Haughton, Tim. 2005. Constraints and Opportunities of Leadership in Post-Communist Europe. Farnham: Ashgate.

Haughton, Tim, Tereza Novotna, and Kevin Deegan-Krause. 2011. The 2010 Czech and Slovak Parliamentary Elections: Red Cards to the Winners. West European Politics 34 (2): 394-402.

Hayoz, Nicolas, and Nicole Gallina. 2011. Beyond Democracy: The Relevance of Informal Power in Eastern Europe. In Twenty Years After the Collapse of Communism, eds. Nicolas Hayoz, Daniela Koleva and Leszek Jesien, 119-142. Bern: Peter Lang Verlag.

Henderson, Karen. 2002. Slovakia: The Escape from Invisibility. New York: Routledge.

Higley, John, and György Lengyel, eds. 2000. Elites after State Socialism: Theories and Analysis. Lanham: Rowman and Littlefield.

Higley, John, and Michael G. Burton. 2006. The Foundations of Liberal Democracy. Lanham: Rowman and Littlefield.

Hospodarské, Noviny. 2007. Július Rezeš: Kto chce robit' vel'ký biznis, musí sa kamarátit's politikmi. 23.04.07.

Idnes.cz. 2000. Novák znal celou pravdu už dávno. 09.06.00. http://zpravy.idnes.cz/novak-znalcelou-pravdu-uz-davno-don-/domaci.aspx?c=A000609083759domaci_mhk. Accessed 15 Nov 2011.

Javůrek, Peter. 2007. Skončila éra Majského. Respekt. 07.05.07.

Javůrek, Peter. 2008. Otevrrít nebo zavřít. Respekt. 02.06.08.

Johnston, Michel. 2001. The Definitions Debate: Old conflicts in New Guises. In The Political Economy of Corruption, ed. Jain K. Arvind, 11-32. London: Routlege.

Jordan, Jeffrey M. 2002. Patronage and Corruption in the Czech Republic. SAIS Review 22 (2): $19-52$.

Kitschelt, Herbert. 2001. Partisan Competition and Welfare State Retrenchment: When Do Politicians Choose Unpopular Politics? In The New Politics of the Welfare State, ed. Paul Pierson, 265-302. Oxford: Oxford University Press.

Kmenta, Jaroslav. 2007. Kmotr Mrázek. Prague: Nakadatelství JKM - Jaroslav Kmenta.

Kmenta, Jaroslav. 2008. Kmotr Mrázek II (Krakatice). Prague: Nakladatelství JKM - Jaroslav Kmenta.

Kopecký, Petr. 1995. Developing Party Organisations in East Central Europe. Party Politics 1 (4): 515-534.

Kopecký, Petr. 2006. Political Parties and the State in Post-Communist Europe: The Nature of Symbiosis. Journal of Communist Studies and Transition Politics 22 (3): 251-273.

Kotkin, Stephen, and András Sajó. 2002. Political Corruption in Transition. A Skeptic's Handbook. Budapest: Central European University Press.

Krastev, Ivan. 2004. Shifting Obsessions: Three Essays on the Politics of Anticorruption. Budapest: Central European University Press.

Kudrna, Tomáš, and Katka Volná. 2007. Vládneme nerušit. Documentary under: http://www.youtube.com/watch?v=h7UZZkCSXts. Accessed 10 Aug 2011.

Kundra, Ondřej, and Jaroslav Spurný. 2008. Dědictví mafianá Mrázka. Respekt. 02.06.08.

Kundra, Ondřej. 2010. Novy život lovce mafiánu Respekt. 19.07.10.

Kundra, Ondřej. 2011. Vzpoura detektiva Mazánka. Respekt. 03.10.11.

Kundra, Ondřej. 2012. Lessy dojel na Právo. Respekt. 03.08.12.

Kurian, Matej. 2012. Recent Slovak Anti-corruption Measures. Bratislava: Transparency International Slovakia.

Lammers, Joris, Adam D. Galinsky, Ernestine H., Gordijn, and Sabine Otten. 2008. Illegitimacy Moderates the Effect of Power on Approach. Psychological Science 19 (6): 558-564.

Lauth, Hans-Joachim. 2000. Informal Institutions and Democracy. Democratization 7 (4): 21-50. 
Lauth, Hans-Joachim. 2004. Formal and Informal Institutions: On Structuring Their Mutual CoExistence. Romanian Journal of Political Science 4 (1): 66-88.

Lewis, Paul G, ed. 1996. Party Structure and Organisation in East Central Europe. Cheltenham: Edward Elgar.

Lidové Noviny. 2007. Výchova premiéra. 24.11.07.

Lízal, Lubomír, and Evzen Kocenda. 2001. State of Corruption in Transition: The Case of the Czech Republic. Emerging Markets Review 2 (2): 138-160.

Malova, Darina, Jean Blondel, and Ferdinand Müller-Rommel. 2007. Governing New European Democracies. London: Palgrave Macmillan.

Merkel, Wolfgang. 2007. Gegen alle Theorie? Die Konsolidierung der Demokratie in Osteuropa. Politische Vierteljahresschrift 48 (3): 413-433.

Mesežnikov, Grigorij, Ol'ga Gyárfášová, and Daniel Smilov. 2008. Populist Politics and Liberal Democracy in Central and Eastern Europe. Bratislava: Institute for Public Affairs.

Mesežnikov, Grigorij, Miroslav Kollár, and Michal Vašečka. 2009. Slovakia. Nations in Transit 2009. Wahington DC: Freedom House.

Meyer, Gerd, ed. 2008. Formal Institutions and Informal Politics in Central and Eastern Europe. Hungary, Poland, Russia and Ukraine. Opladen \& Farmington Hills: Barbara Budrich Publishers.

Miller, William L., Åse B. Grødeland, and Tatyana Y. Koshechkina, eds. 2000. A Culture of Corruption? Coping with Government in Post-communist Europe. Budapest: Central European University Press.

Mladá Fronta Dnes. 2006. Politici bráni vyšetřování. 30.05.06.

Mladá Fronta Dnes. 2007. Grossův majetek. 09.10.07.

Mladá Fronta Dnes. 2010. Prezident ví všechno. 12.08.10.

Mladá Fronta Dnes. 2013. Amnestie bobtná, trestu unikne přes 50 tisic lidí. 12.03.13.

Mungiu-Pippidi, Alina. 2006. Corruption: Diagnosis and Treatment. Democratization 17 (3): 86-99.

MVČR. 2003. Zpráva o korupci v České republice v roce 2002 a o plnění harmonogramu opatření Vládniho programu boje proti korupci. Praha: Ministerstvo vnitra České republiky.

MVČR. 2006. Strategie vlády v boji proti korupci 2006-2011. Praha: Ministerstvo vnitra České republiky.

MVČR. 2007. Zpráva o korupci v Ceské republice v letech 2005-2006 a o plnení Aktualizovaného Vládního programu boje proti korupci. Praha: Ministerstvo vnitra České republiky

MVČR. 2008. Reforma policie $\check{C} R$. Legislativni Část. Praha: Ministerstvo vnitra České republiky.

Myant, Martin R. 2003. The Rise and Fall of Czech Capitalism. Cheltenham: Edward Elgar.

Neue Zürcher Zeitung. (NZZ). 2012. Bundesanwaltschaft will 600 Millionen konfiszieren. http://www.nzz.ch/aktuell/schweiz/bundesanwaltschaft-will-660-millionen-konfiszieren-1.17797721. Accessed 10 Jan 13.

News, BBC. 2010. Slovakia's left-wing PM seeks to form new government. 13.06.10.

Nicholson, Tom. 2012. Gorila. Bratislava: Dixit.

Novinky.cz. 2011. John ve vládě končí. 11.05.11. http://www.novinky.cz/domaci/233065-john-vevlade-konci.html. Accessed 20 June 2011.

Novinky.cz. 2012. Sněmovna vydala Ratha k trestnímu stíhání. 05.06.12. http://www.novinky.cz/ domaci/269613-snemovna-vydala-ratha-k-trestnimu-stihani.html. Accessed 05 Aug 2012.

Pavel, Jan. 2006. Ukazatele transparentnosti trhu veřejných zakázek v České republice. Praha: Transparency International ČR.

Pehe, Jírí. 13. October 2009. Life Beyond Communism: Democracies without Democrats, Transitions Online, Special Report.

Piussi, Zuzana. Od Fica do Fica. (2010/2012). Documentary under http://www.youtube.com/ watch? $\mathrm{v}=\mathrm{cbVoUjtqkUU}$. Accessed 10 Jan 2013. 
Piussi, Zuzana. 2011. Nemoc tretej moci. Documentary under http://ishare.rediff.com/video/others/ nemoc-tretej-moci-2011-/7184664. Accessed 10 Jan 2013.

Prague Post. 2011. Slovak PM vows corruption fight. 17.08.11.

Prague Post. 2012. Tapes reveal collusion of Janoušek and Bém. 28.03.12. http://www.praguepost. com/news/12636-tapes-detail-collusion-of-janousek-bem.html. Accessed 10 Aug 2012.

Radio Prag. 2001. Klage gegen die investigative Wochenzeitung Respekt. 30.11.01.

Radio Prague. 2005. Chief aide to prime minister sacked over alleged corruption. 29.08.05.

Radio Prag. 2006a. Transparency International kritisiert tschechische Politik wegen laxer Haltung zur Korruption. 27.09.06.

Radio Prague. 2006b. "Mafia boss" Berdych and gang appear in court. 02.02.06.

Radio Prag. 2007a. Alptraum-Prozess Uzunoglu. 01.08.07.

Radio Prag. 2007b. Regierung will stärker gegen Korruption vorgehen. 19.06.07.

Radio Prague. 2007c. Kubice report challenged by supreme state attorneys office. 25.04.07.

Radio Prag. 2008. Politologe Schuster: Kočka-Mord könnte Politikverdrossenheit verstärken. 13.10.08.

Radio Prague. 2009. Plzen law school scandal provokes nation-wide audit of over 300.000 university graduates. 20.10.09.

Radio Prague. 2010a. Controversial Czech institute sets new course with new director. 18.02.10.

Radio Prag. 2010b. Korruption im Verteidigungsressort: stellvertretender Minister entlassen. 02.09.10.

Radio Prag. 2011a. Über 1000 aktive Richter und Staatsanwälte haben kommunistische Parteivergangenheit. 07.01.11.

Radio Prag. 2011b. Magazin Respekt: Acht Milliarden Kronen Schaden für den tschechischen Staat bei MUS-Privatisierung. 21.11.11.

Radio Prag. 2011c. Die graue Parteieminenz: Verkehrsminister Bárta ist zurückgetreten. 08.04.11.

Radio Prag. 2011d. Führende Kriminalbeamte sind desillusioniert und wollen die Polizei verlassen. 06.10 .11 .

Radio Prag. 2011e. Sonderabteilung der Staatsanwaltschaft für schwerwiegende Wirtschaftskriminalität und Korruption soll entstehen. 17.10.11.

Radio Prag. 2011f. Neue Ermittlungen gegen Ex-Umweltminister Pavel Drobil wegen Korruptionsverdachts angeordnet. 16.11.11.

Radio Prague. 2013a. Ministers clear their desks as Nečas government bows out. 03.07.13.

Radio Prague. 2013b. Court rules ex-MPs'alleged bribe taking covered by immunity. 17.07.13.

Respekt. 2011a. Kudy z bahna. 10.01.11.

Respekt. 2011b. Policie je děravá jako cednik. Interview with Jan Kubice. 13.11.11.

Rose-Ackerman, Susan. 1978. Corruption: A Study in Political Economy. New York: Academic Press.

Rose-Ackerman, Susan. 1999. Corruption and Government. Causes, Consequences and Reform. Cambridge: Cambridge University Press.

Rose-Ackerman, Susan. 2001. Political Corruption and Democratic Structures. In The Political Economy of Corruption, ed. Jain K. Arvind, 35-62. London: Routledge.

Rousso, Alan, and Franklin Steves. 2006. The Effectiveness of Anti-corruption Programs: Preliminary Evidence from the Post-communist Transition Countries. In International Handbook on the Economics of Corruption, ed. Susan Rose-Ackerman, 247-277. Cheltenham: Edward Elgar.

Rozhlas. 2012. Policie obvinila Ratha z přijetí úplatku, našla u něj sedm milionů. http://m.rozhlas. cz/zpravy/politika/_zprava/statni-zastupkyne-bradacova-u-ratha-jsme-nalezli-sedm-milionukorun-1059707. Accessed 15 Aug 2012.

Schmid, Ulrich. 2006. Prekäre Neuausrichtung in der Slowakei. Neue Zürcher Zeitung 11.09.06.

Schmid, Ulrich. 2008. Rückkehr Cuneks in Tschechiens Regierung. Neue Zürcher Zeitung 03.04.08. 
Sičáková, Emília, et al. 2002. Protikorupčné Minimum. S’luby a realita boja proti korupcii v SR a odporúčánia pre novú vladu. Bratislava: Transparency International Slovensko.

Sičáková-Beblavá, Emília, and Pavel Nechala. 2006. Protikorupčné Minimum. Bratislava: Transparency International Slovensko.

Sičáková-Beblavá, Emilia, and Miroslav Beblavý, eds. 2008. Jedenást'statočných: Prípadové štúdie protikorupčných nástrojov na Slovensku. Bratislava: Transparency International Slovakia and Public Policy Institute at the Comenius University. Bratislava.

Sičáková-Beblavá, Emilia, Gabriel Šipoš, and Matej Kurian. 2011. Korupcia a protikorupčná politika na Slovensku 1989-2010. Forum Historiae 5 (2). http://www.forumhistoriae.sk/ FH2_2011/texty_2_2011/tis.pdf. Accessed 10 Mar 2012.

Šimečka, Martin M. 2011a. Piráti u moci. Respekt. 03.01.11.

Šimečka, Martin M. 2011b. Průhledností proti korupci. Respekt. 11.01.11.

Šimečka, Martin M. 2012. The crooked judges of Slovakia. Respekt. 19.11.12. Excerpts, translated in http://www.presseurop.eu/en/content/article/3041771-crooked-judges-slovakia. Accessed 10 Jan 2013.

Šipoš, Gabriel Emilia Sičáková-Beblavá, and Tomáš Jacko. 2010. Protikorupčné Minimum. Hodonotenia, odporúčania a stav korupcie na Slovensku. Bratislava: Transparency International Slovenko.

SME. 2010. Bugár: Trnka? Obrovská chyba. 23.10.10.

SME. 2013a. Harabin sa opät' súdi. 25.06.13.

SME. 2013b. Smer dostal svojho prokurátora. 17.07.13.

Spinney, Laura. 2011. The Underhand Ape: Why Corruption is Normal. The New Scientist 2837, 02.11.11.

Spurný, Jaroslav. 2006. ČSSD a organizovaný zločin. Respekt. 26.05.06.

Spurný, Jaroslav. 2007a. Recepty proti korupci. Respekt. 18.12.07.

Spurný, Jaroslav. 2007b. Korupce jako porucha. Respekt. 02.04.07.

Spurný, Jaroslav. 2007c. Grossův tajemný sponzor. Respekt. 08.10.07.

Spurný, Jaroslav. 2007d. 30 vražd kolem Mrázka. Respekt. 12.02.07.

Spurný, Jaroslav. 2008a. Policie odkrývá své práskače. Respekt. 14.01.08.

Spurný, Jaroslav. 2008b. Uplácet bude těžší. Respekt. 07.01.08.

Spurný, Jaroslav, Tomáš Sacher, and Ondřej Kundra. 2008. Vláda v pasti justiční mafie. Respekt. 17.05.08.

Spurný, Jaroslav. 2010. Proč Topolánek neodstoupil. Respekt. 24.03.10.

Spurný, Jaroslav. 2011. Vzpoura policistů. Respekt. 27.07.11.

Spurný, Jaroslav, and Ondřej Kundra. 2012. Červàček je perfektní a nezávislost trvá. Interview with Interior Minister Jan Kubice. Respekt. 03.09.12.

Tabery, Erik. 2008. Vládneme nerušit. Praha: Respekt edice.

Tanzi, Vito. 1998. Corruption Around the World. Causes, Consequences, Scope and Cures. IMF Staff Papers 45 (4): 559-594.

The Economist. 2011. Czech Republic: state capture. 02.11.11.

The Prague Post. 2010. Ministry defends anti-corruption plan. 22.09.10.

The Slovak Spectator. 2001. EU funding scandal: Hell hath no fury. 07.05.01.

The Slovak Spectator. 2006. Special court wins reprieve ... for now. 02.10.06.

The Slovak Spectator. 2007. ÚPN: Ján Langoš did not lose Široký file. 27.01.07.

The Slovak Spectator. 2008. Former minister still working for justice. 14.01.08.

The Slovak Spectator. 2010a. Anti-Corruption Office faces its own accusations. 26.04.10.

The Slovak Spectator. 2010b. All Slovak government contracts will be published on the Internet. 19.10.10.

The Slovak Spectator. 2011. Minister announces "biggest reform of Police Corps for decades". 14.01.11.

The Slovak Spectator. 2013. Filmmaker sees charges dropped. 28.01.13. 
The World Bank. 2000a. Helping Countries Combat Corruption. Washington, DC: The World Bank. http://www.worldbank.org/publicsector/anticorrupt/helpingcountries.pdf. Accessed 05 Nov 2011.

The World Bank. 2000b. Korupcia na Slovensku: Výsledky diagnostických prieskumov. Washington, DC: The World Bank.

Thompson, Dennis F. 1993. Mediated Corruption: The Case of the Keating Five. American Political Science Review 87: 369-3681.

Transparency International. 2006. Corruption Percepetions Index 2007. http://www.transparency. org/cpi2007/results. Accessed 05 Nov 2011.

Transparency International. 2009. Corruption Percepetions Index 2010. http://www.transparency. org/cpi2010/results. Accessed 05 Nov 2011.

Transparency International. 2010. Corruption Perceptions Index 2011. http://www.transparency. org/cpi2011/results. Accessed 05 Nov 2011.

Transparency International. 2011. Corruption Perceptions Index 2012. http://www.transparency. org/cpi2012/results. Accessed 05 Nov 2012.

Transparency International Czech Republic. 2010. Česká justice - otázka správy a nezávislosti. Praha: Transparency International Czech Republic. http://www.transparency.cz/doc/justice www_1.pdf. Accessed 10 Oct 2012.

Transparency International Slovakia. 2009. Prieskum: Fico aj Dzurinda bojovali s korupciou rovnako slabo. http://www.transparency.sk/sk/fico-aj-dzurinda-bojovali-s-korupciou-rovnako-slabo. Accessed 10 Oct 2012.

Transparency International Slovakia. 2010. Vláda Roberta Fica v boji proti korupci zlyhala. http:// www.transparency.sk/sk/tlacova-konferencia-hodnotenie-vlady-r-fica-a-poslancov-nrsrv-boji-proti-korupcii. Accessed 10 Oct 2012.

Transparency International Slovakia. 2012. Vláda premrhala protikorupčný potenciál kauzy Gorila. http://www.transparency.sk/sk/?s=CPI\&x=0\&y=0. Accessed 10 Dec 2012.

Uhlír, Martin. 2010. Domáci ukol pro Radka Johna. Respekt. 19.07.10.

Vagovič, Marek. 2011. Trnka ako Mečiar, Týždeň. 06.02.11.

Vagovič, Marek, and Martin Hanus. 2011. Bol by to zazrak. Interview with Michael Kovač. Týždeñ. 25.07.11.

Zemanovičová, Daniela, and Emàlia Sičaková. 2001. Transparency and Corruption. In Slovakia 2000. A Gobal Report on the State of Society, eds. Grigorij Mesežnikov, Miroslav Kollár and Tom Nicholson, 439-454. Bratislava: Institute for Public Affairs. 